\title{
Kete: Telling Our Stories Together
}

Horowhenua Library Trust

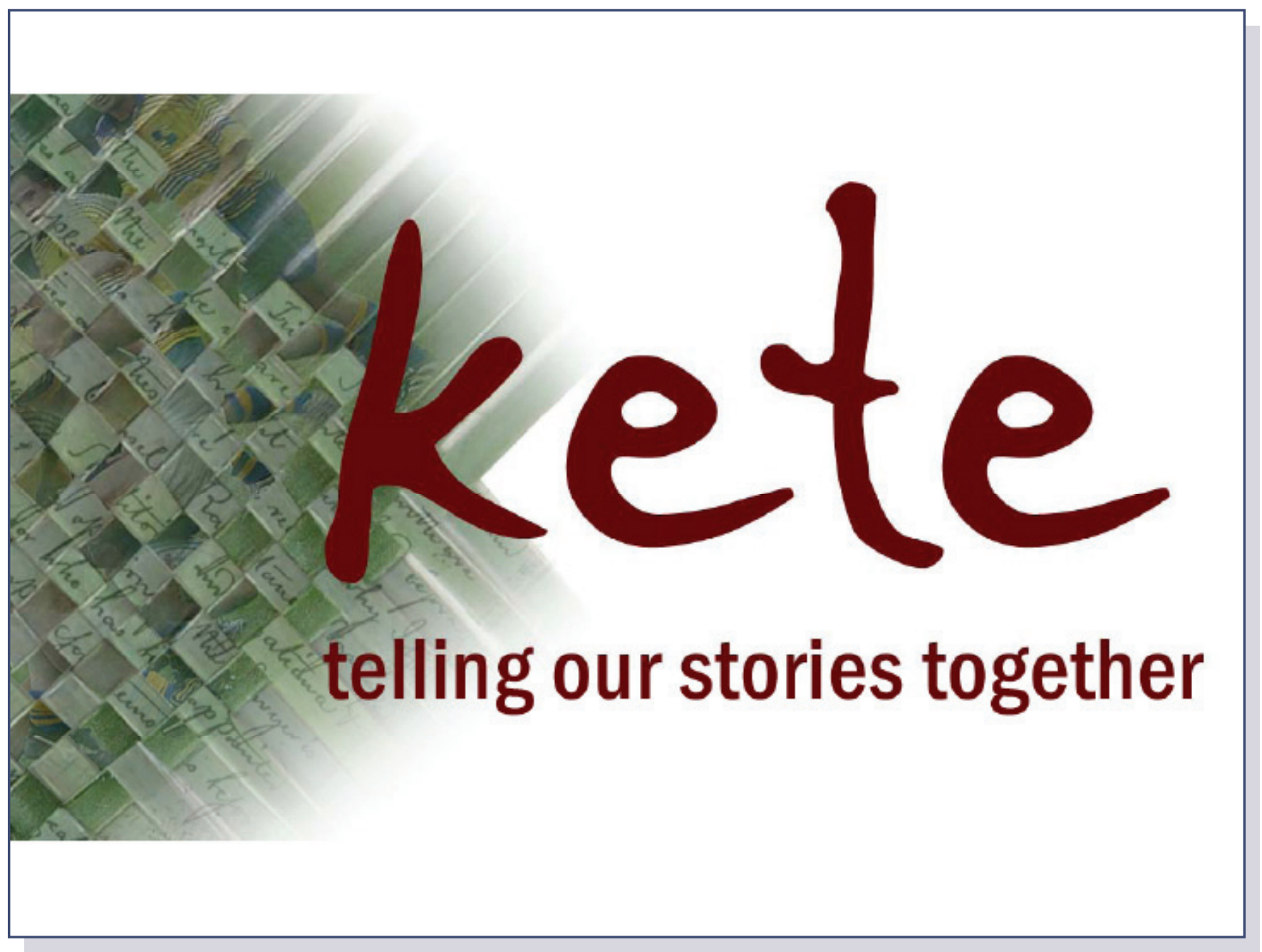




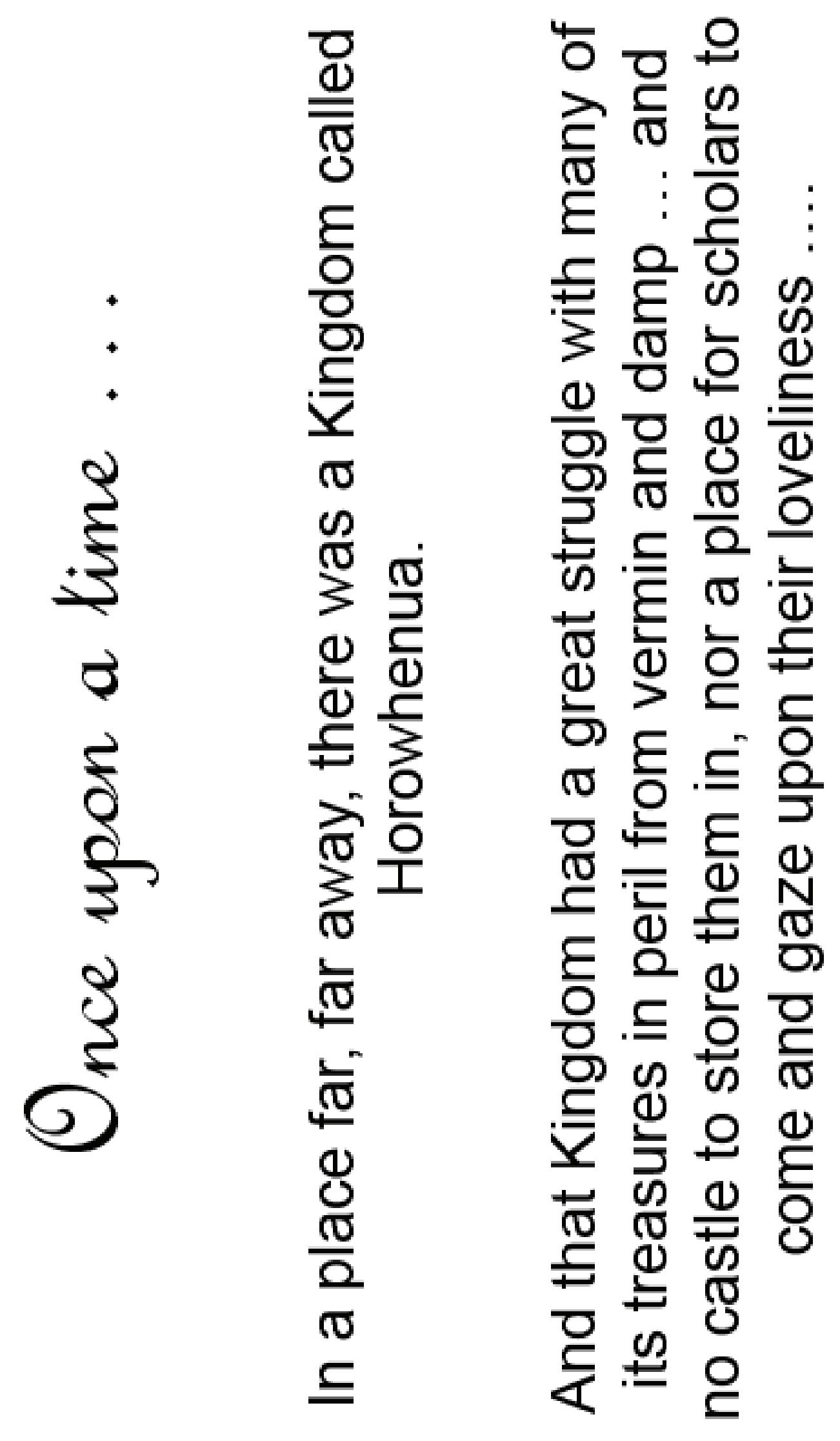




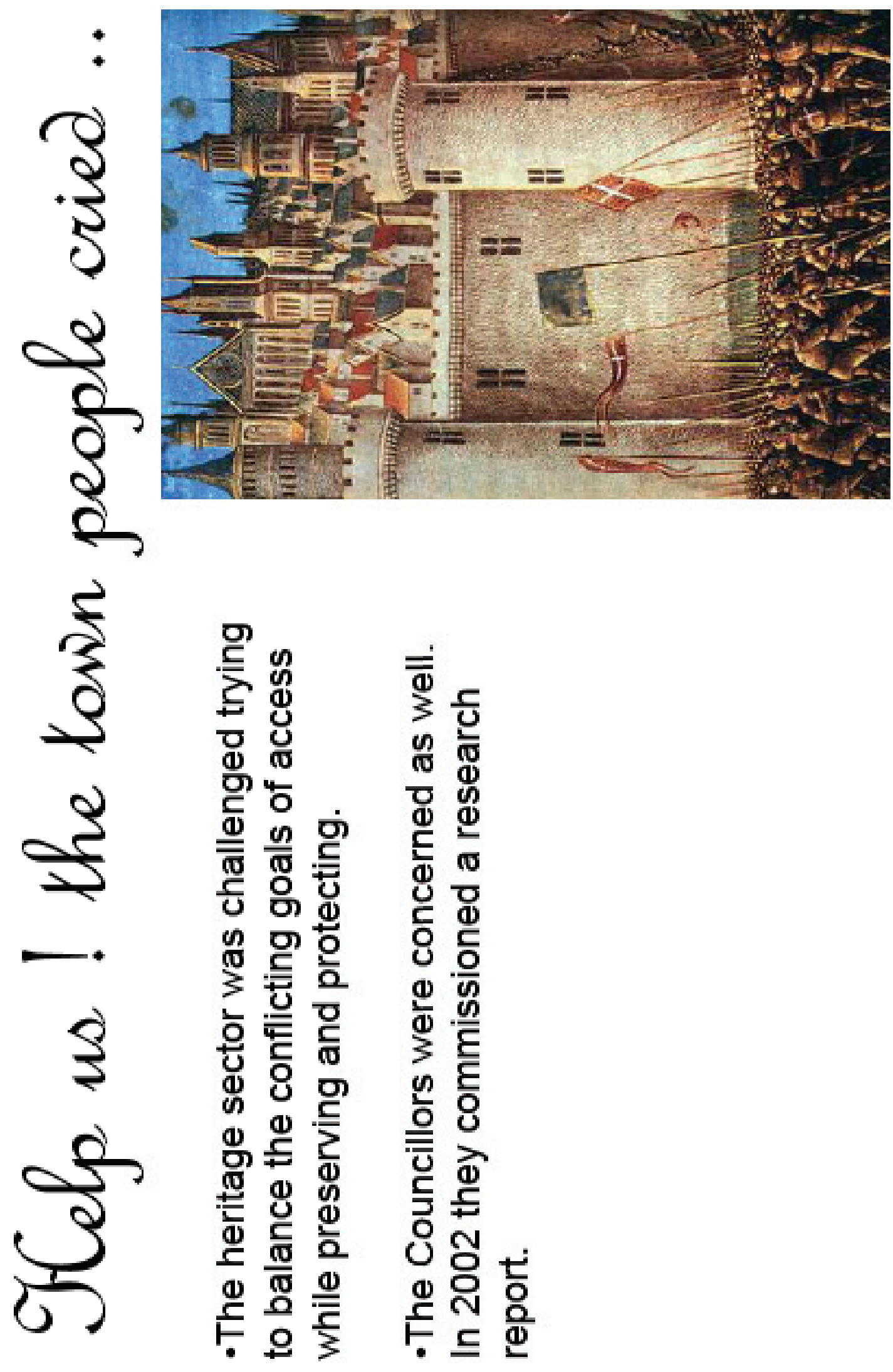




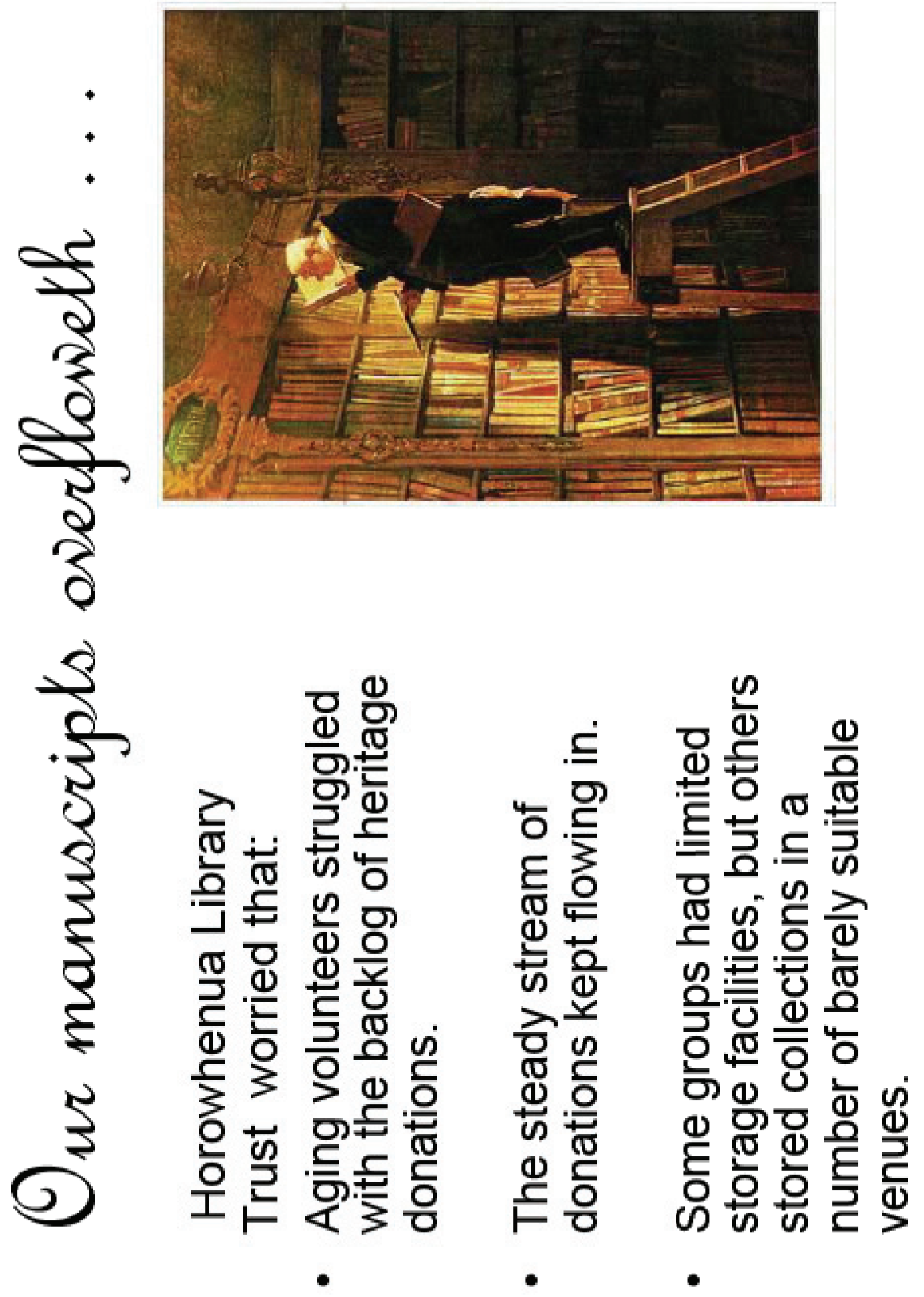




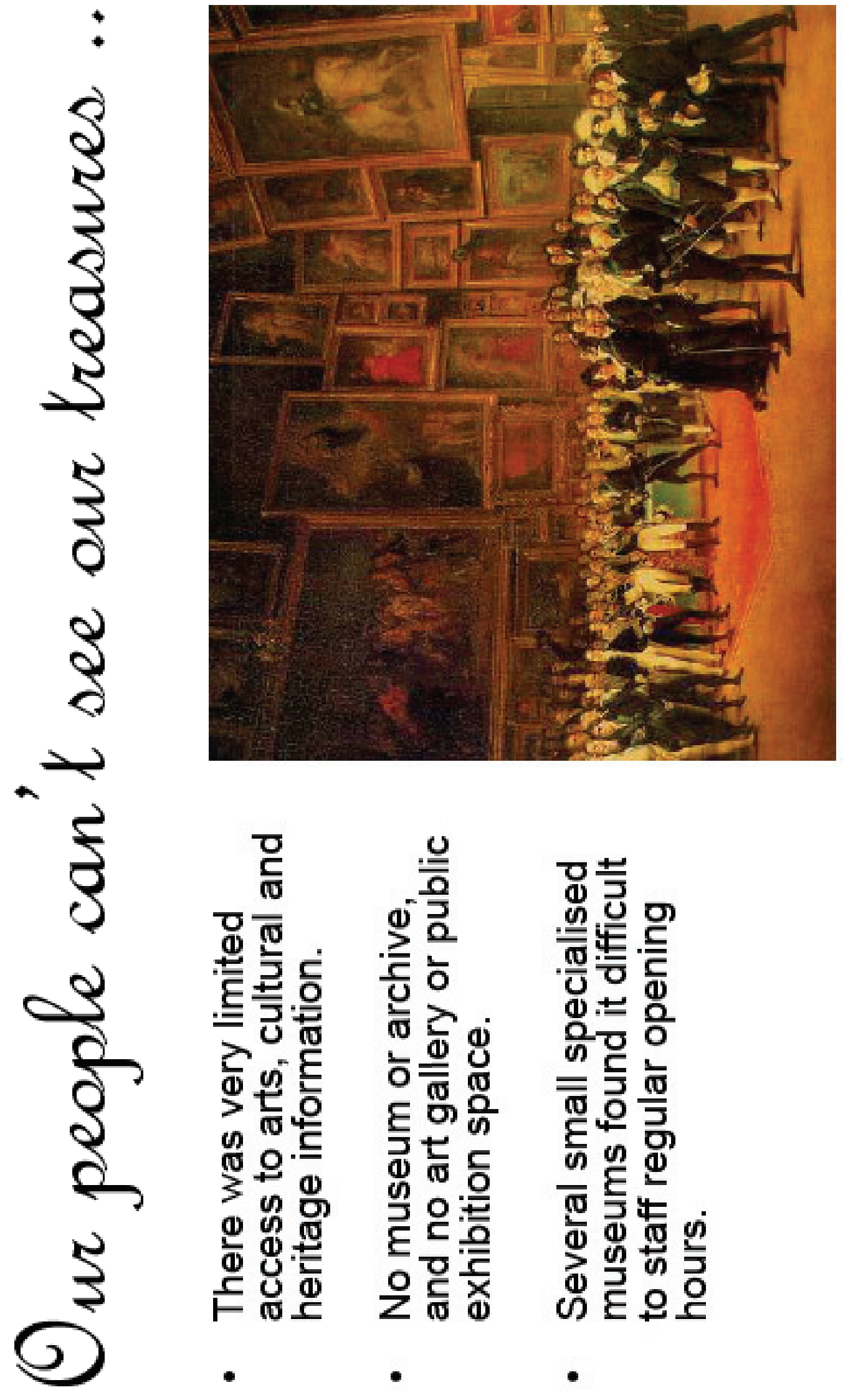




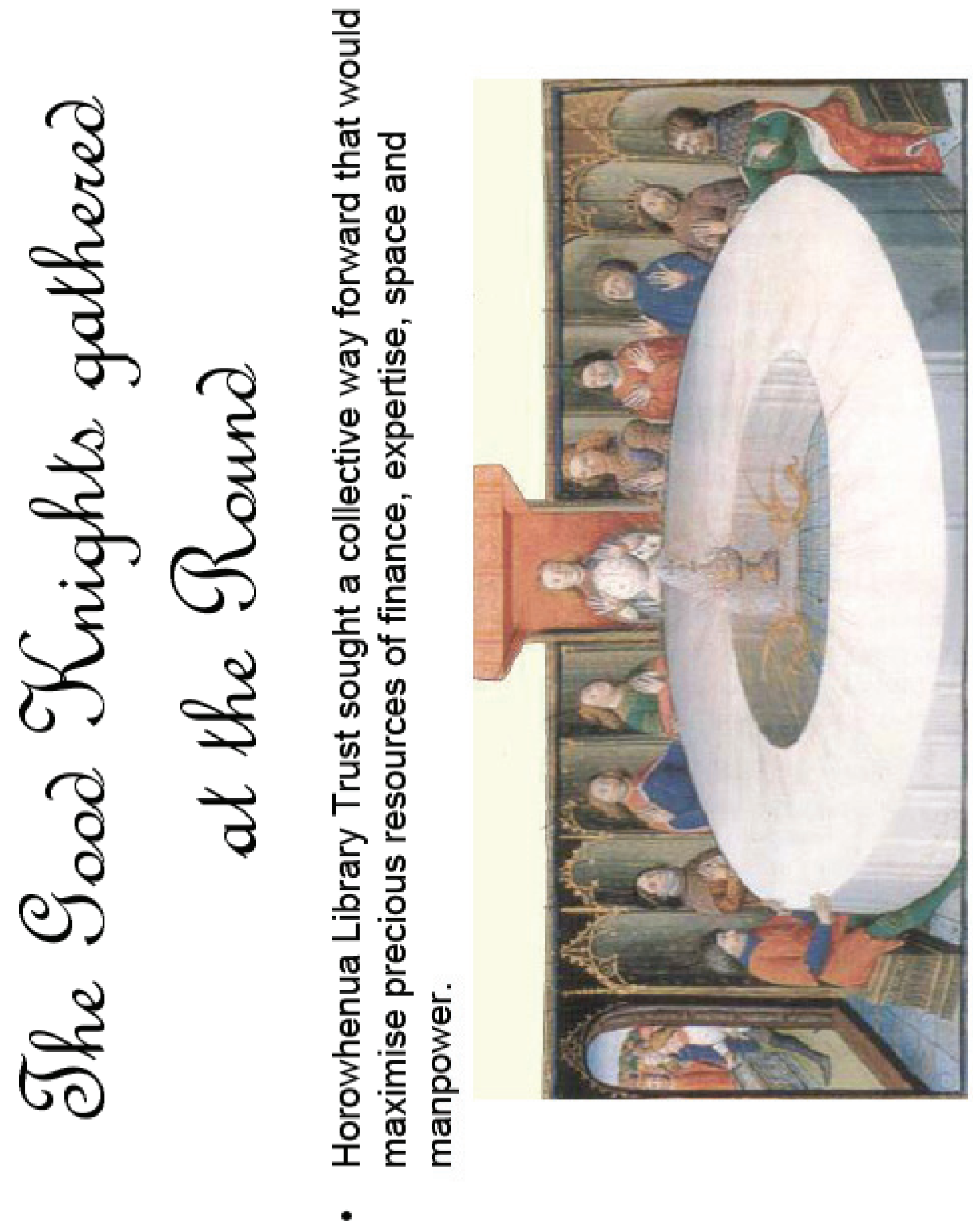




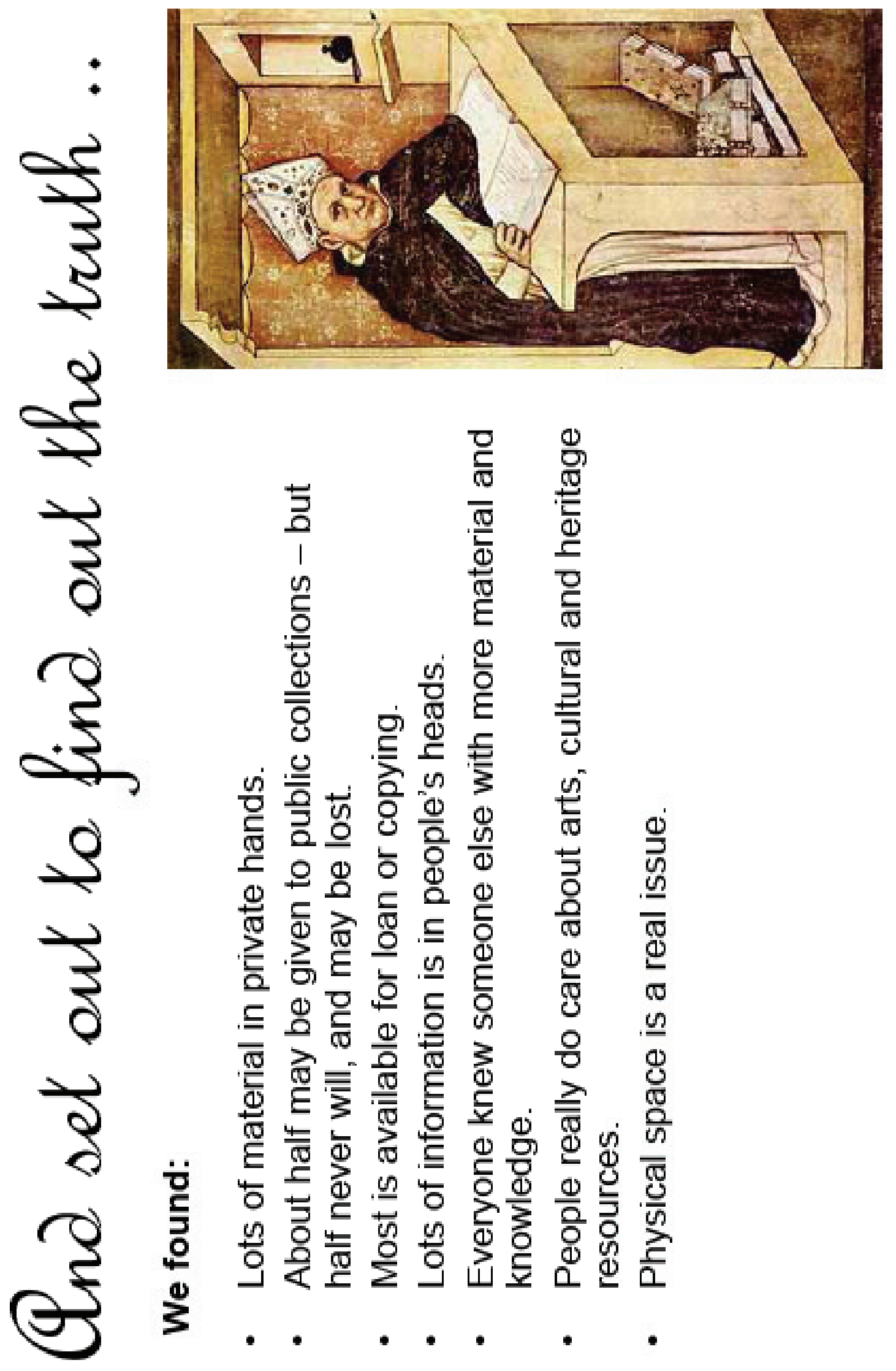



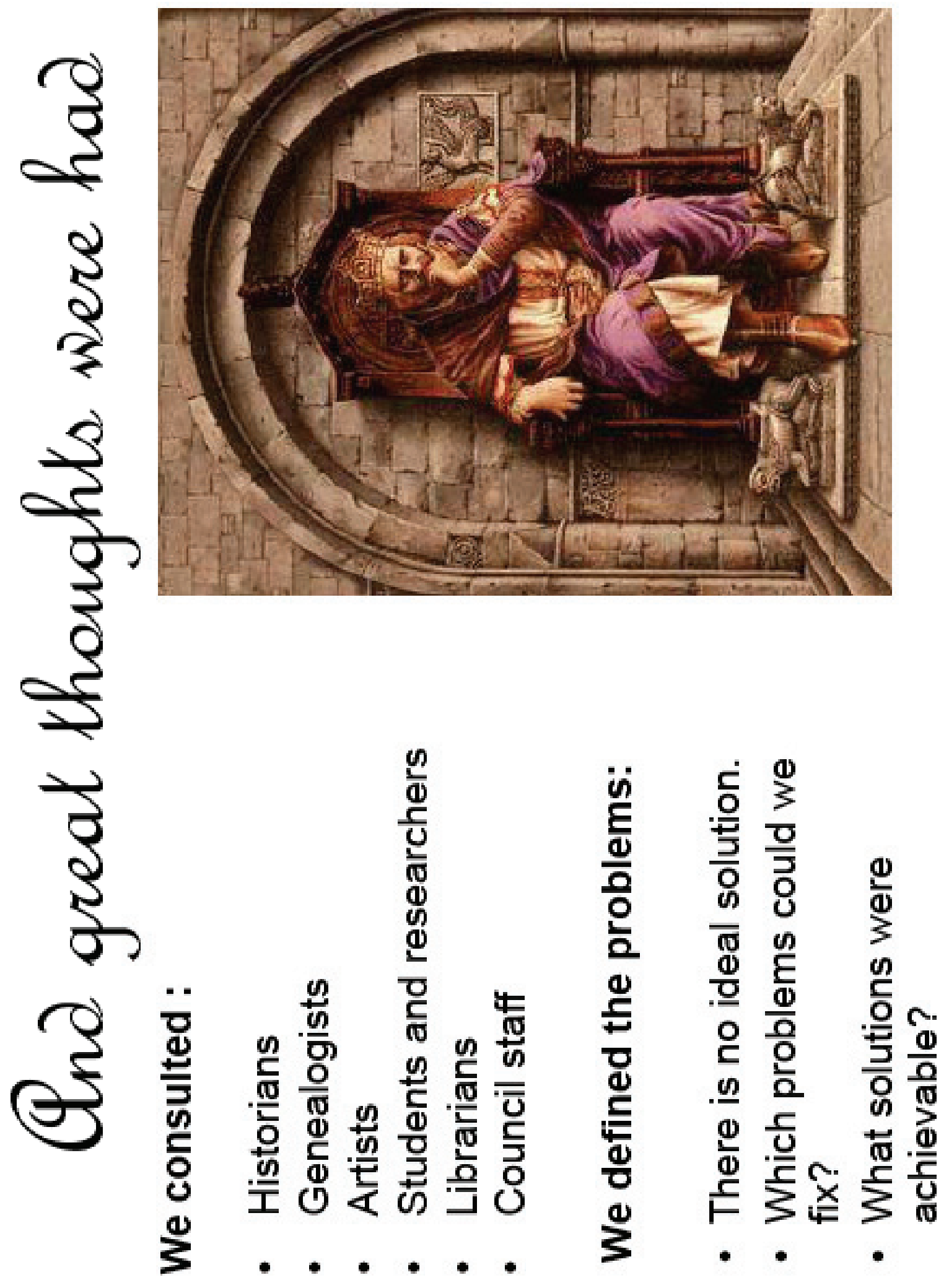

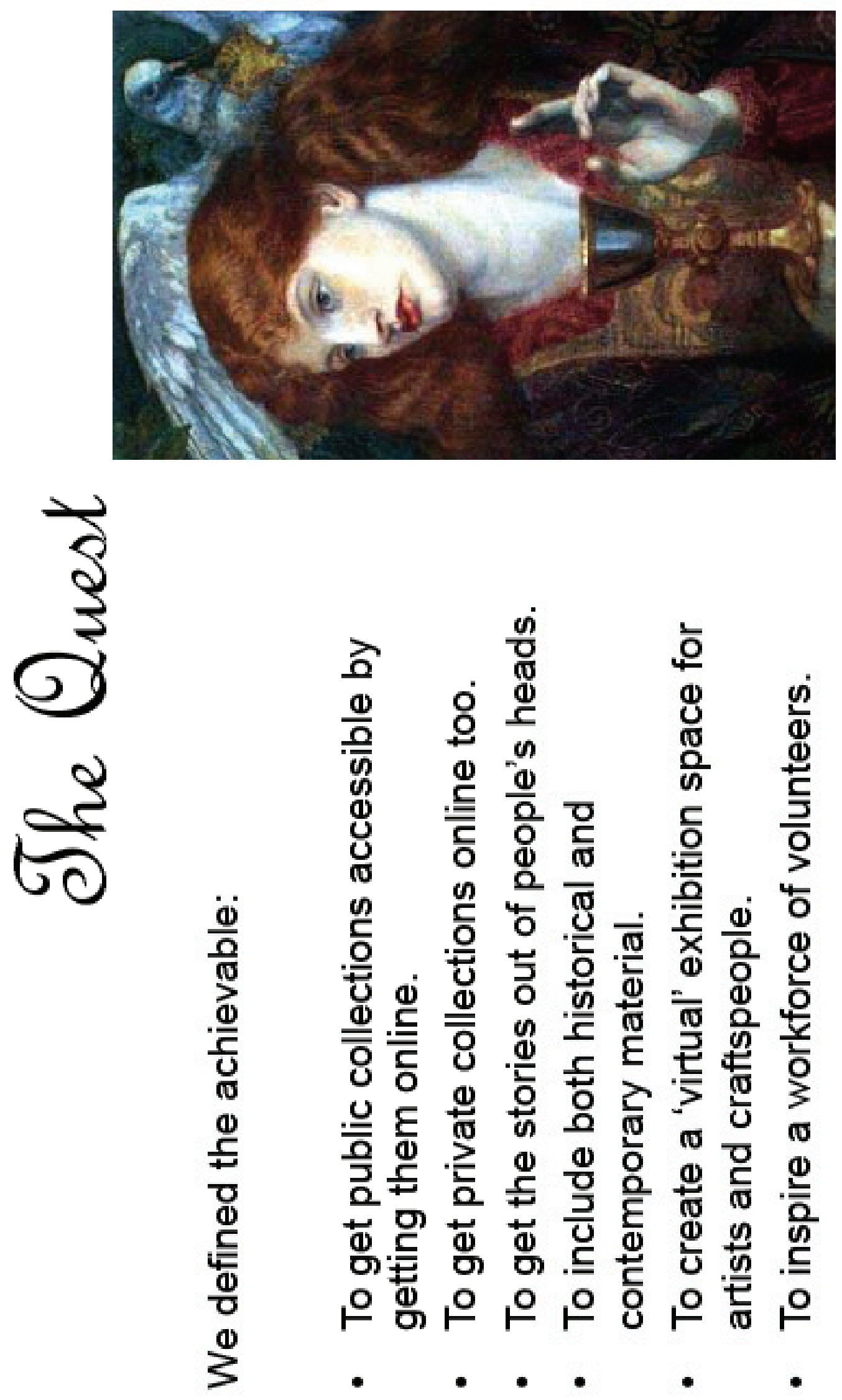


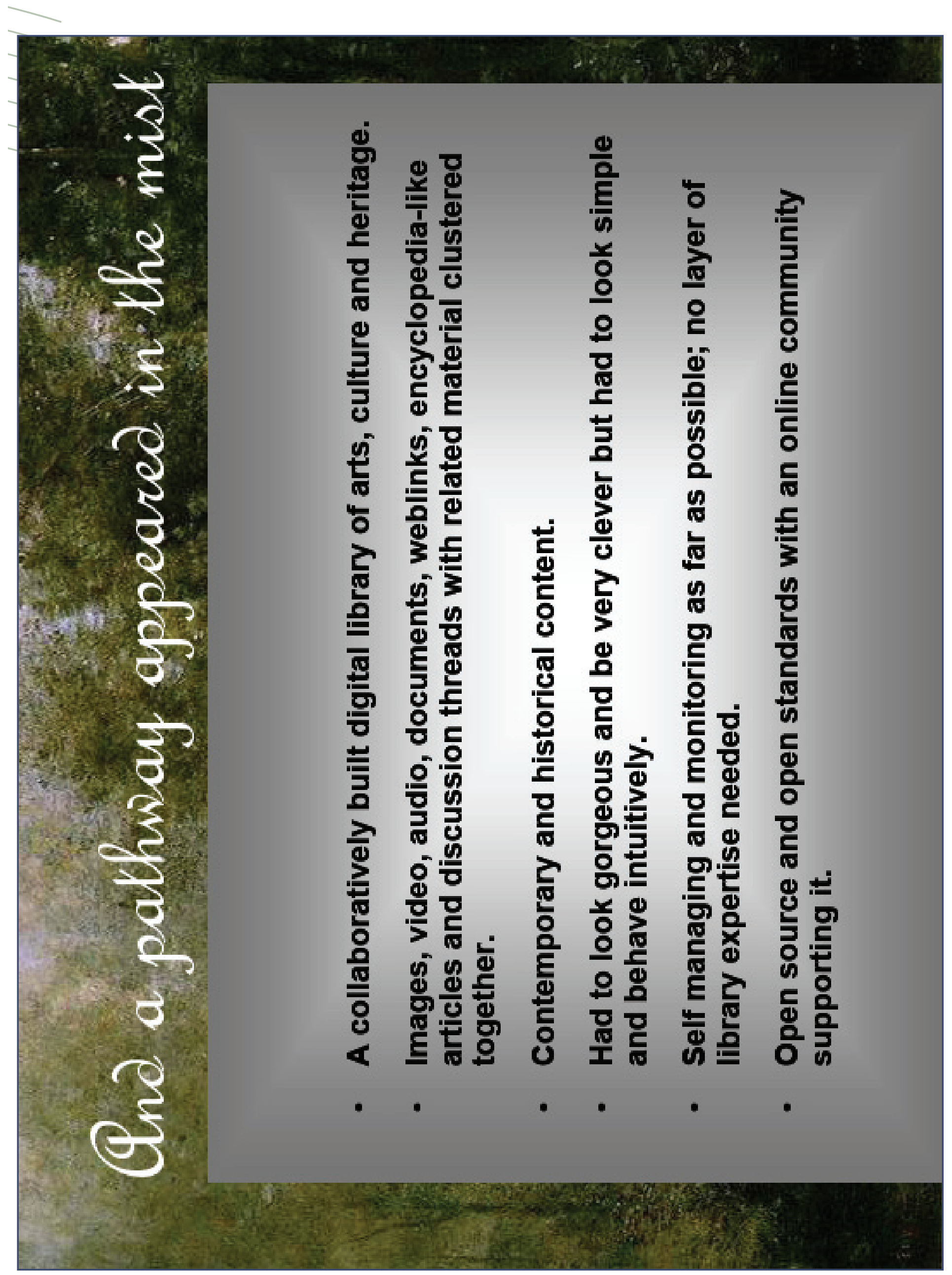



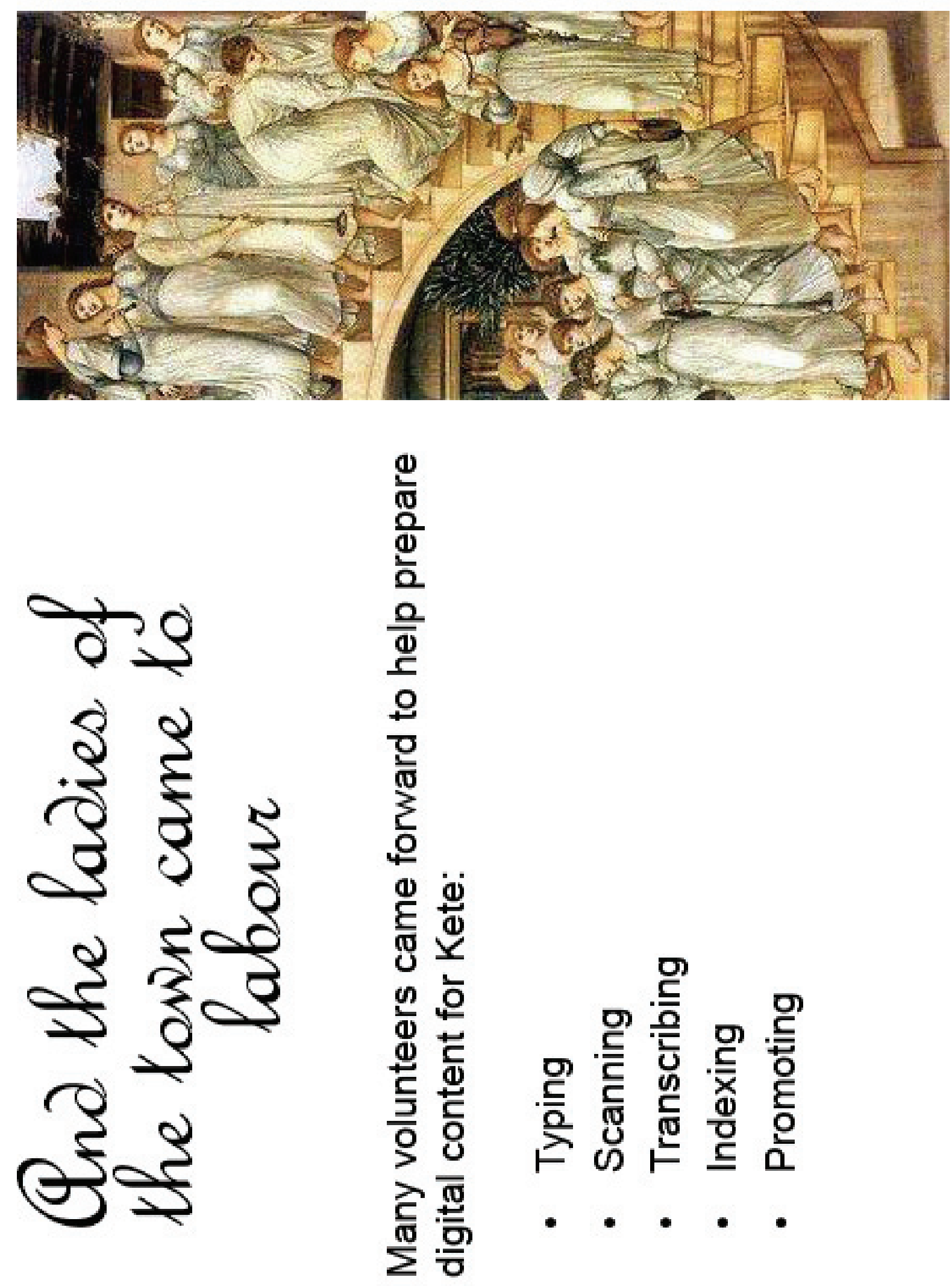


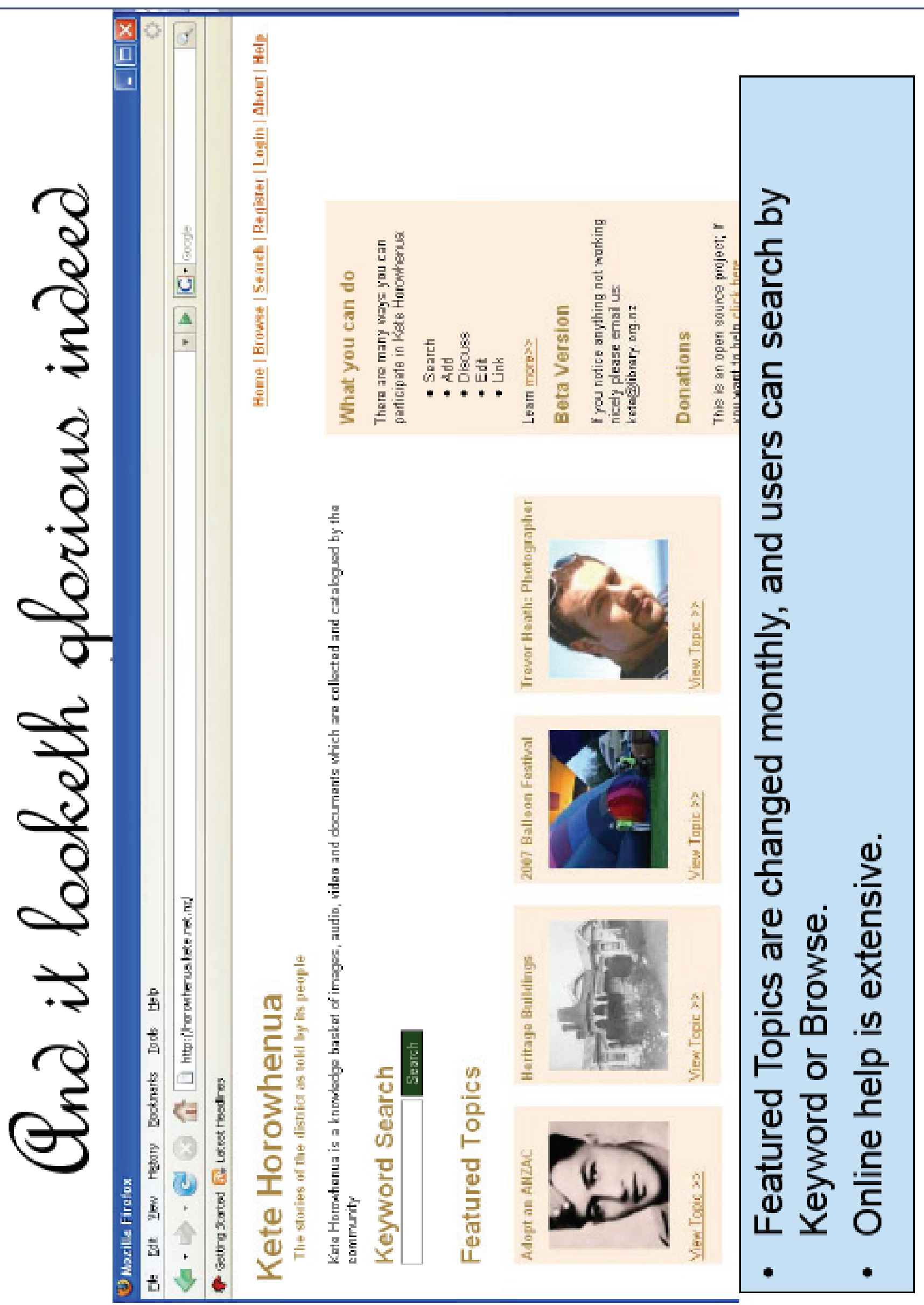




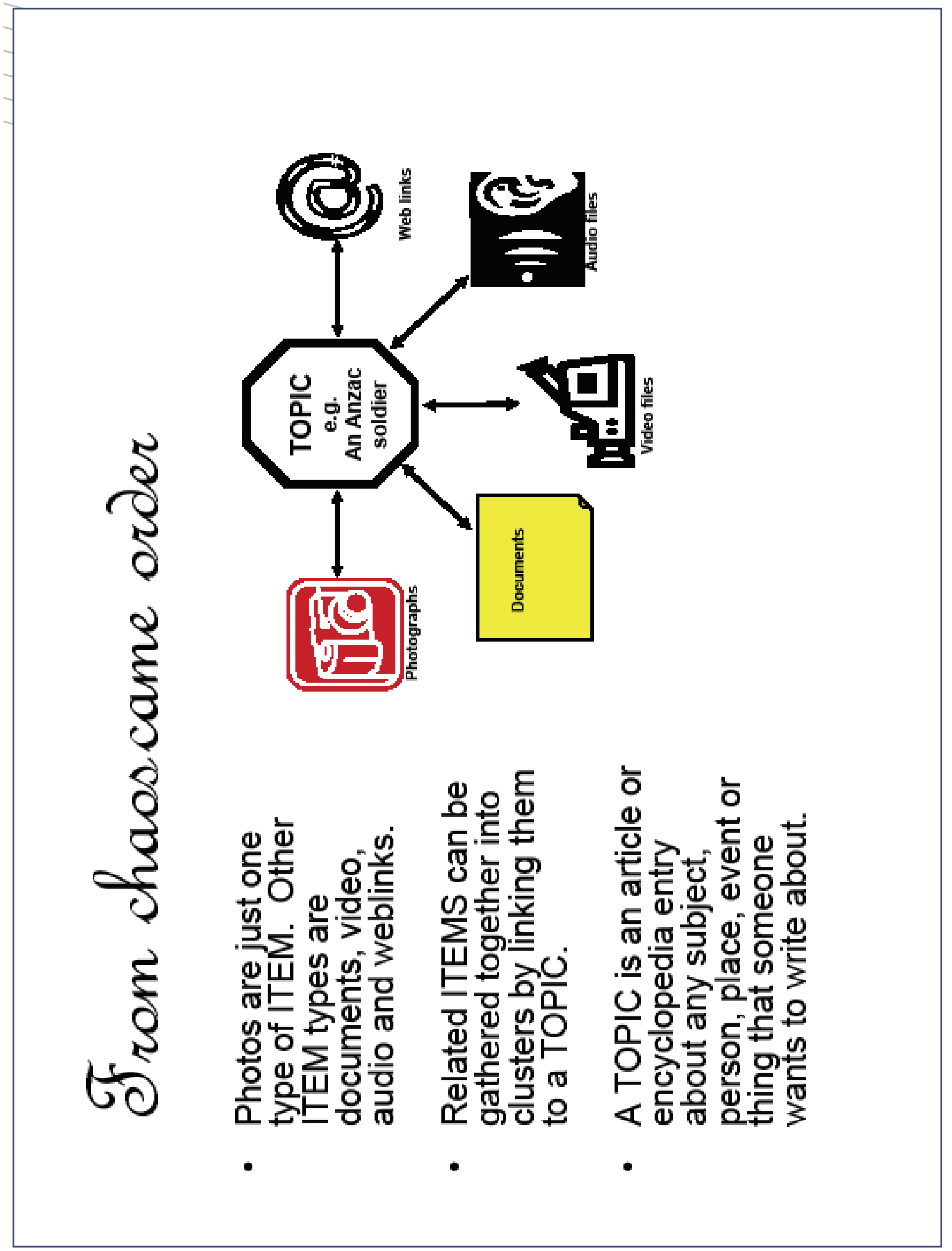




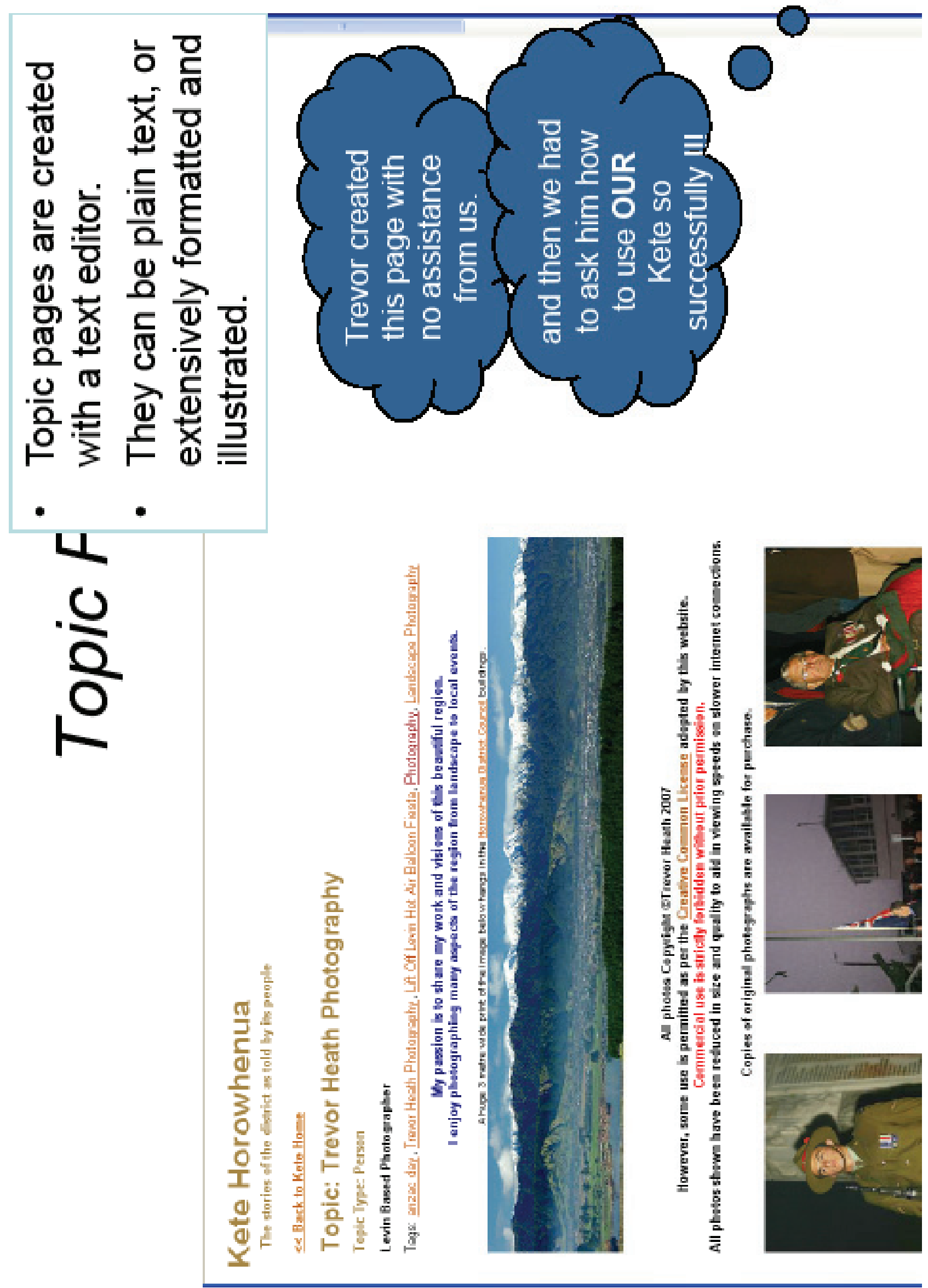




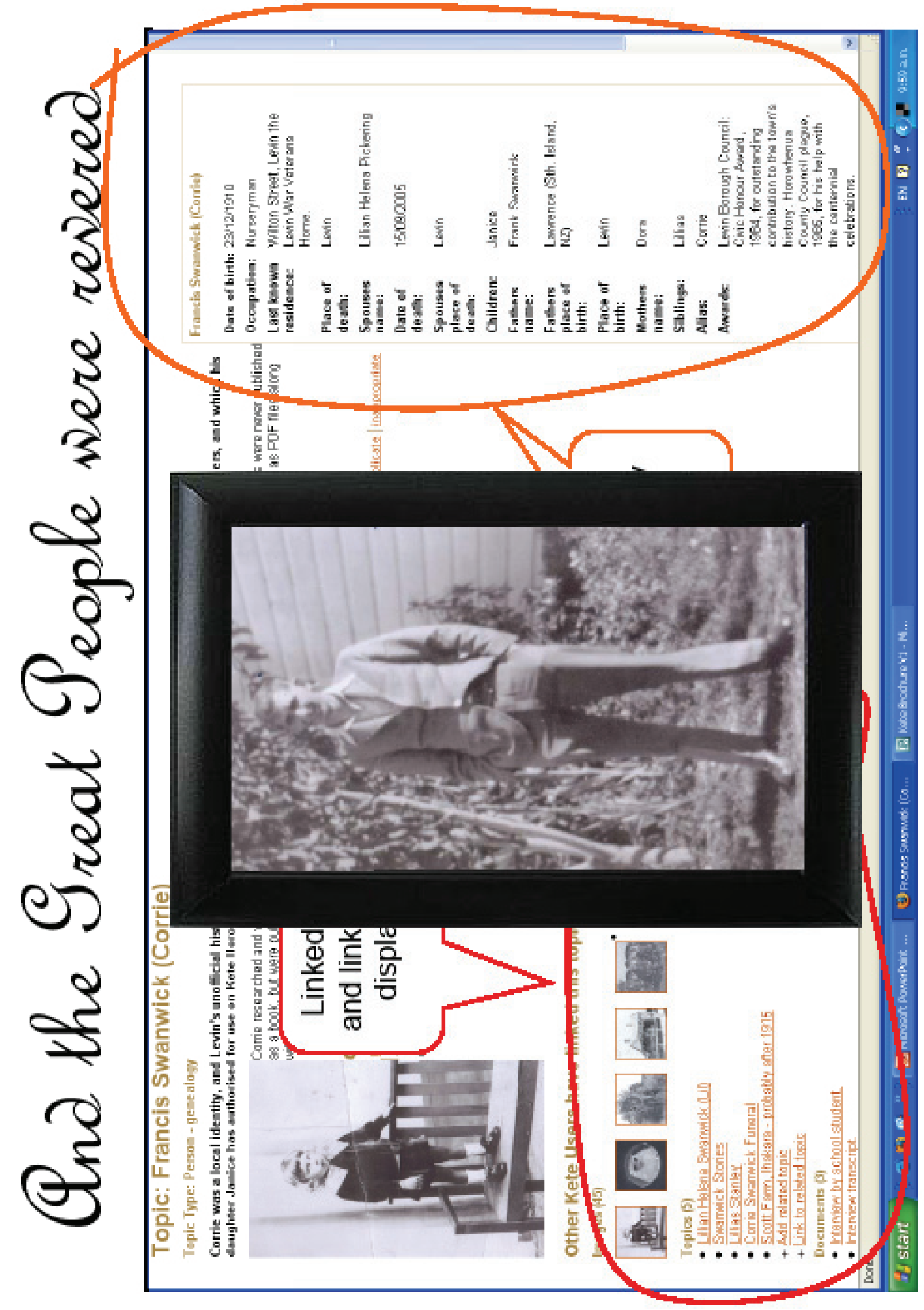



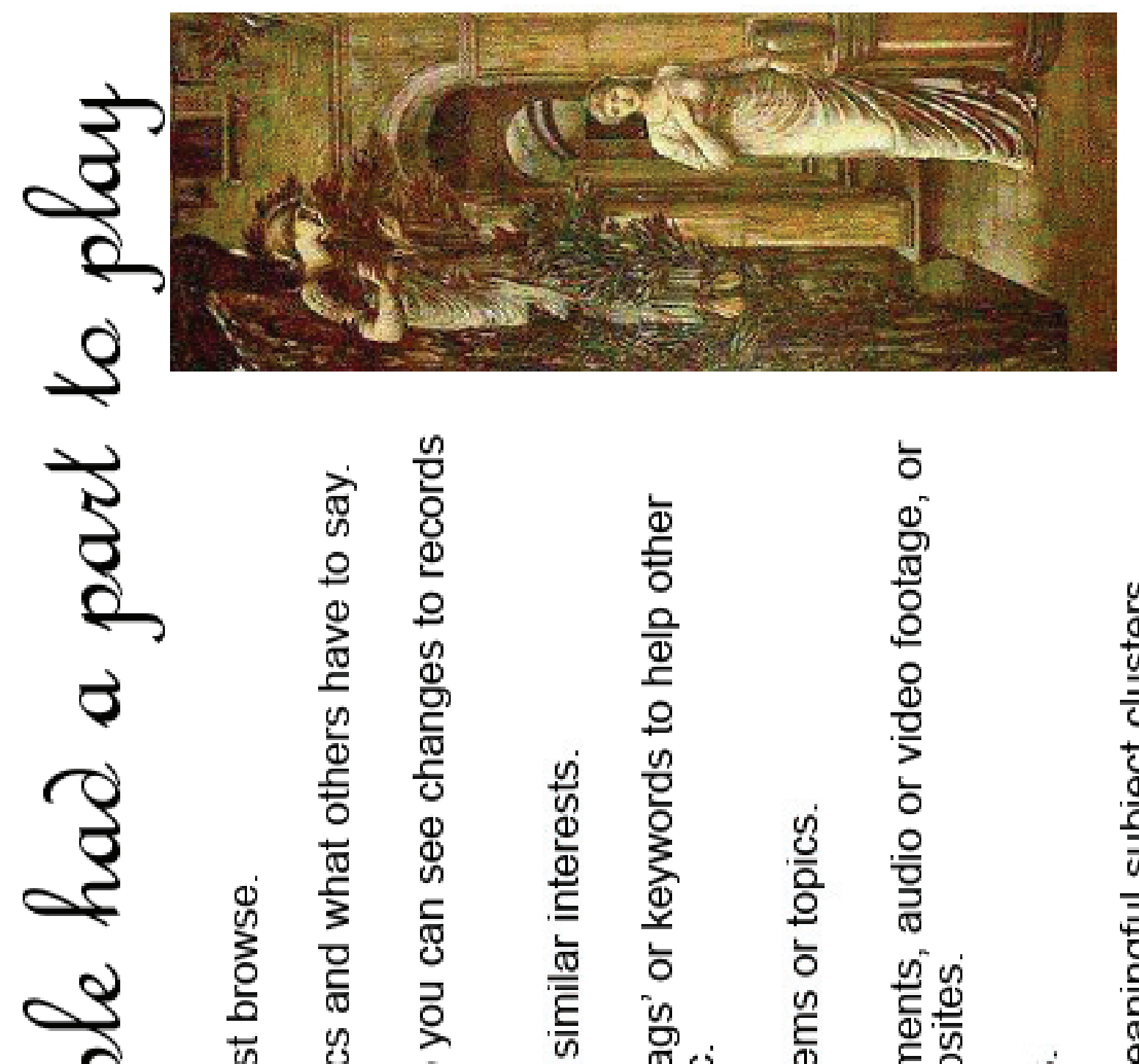

बं

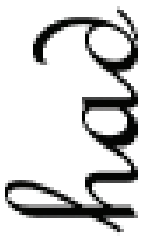

ฮ

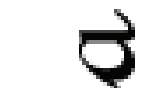

25

ว 징

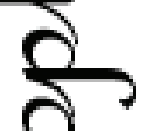

एक

3 흥

क 考

ขึ क्षे

ब‥

\&

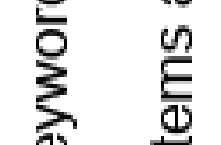

$\overbrace{0}^{2}$

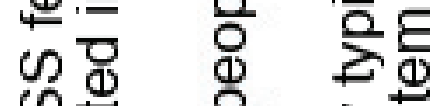

क्ष

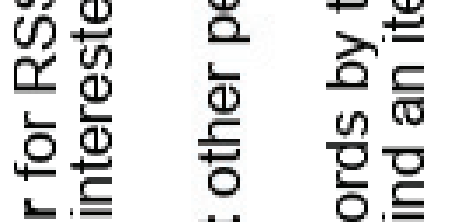

ช

C 느 능

ํㅓㅁ

产恋

늉응

윽

잃

등

告

음 融

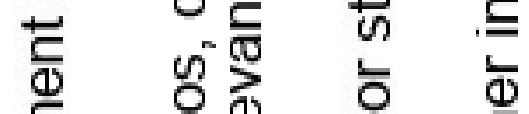

ह

등능

헌은 은

む衣 㐘

๙

o

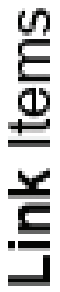




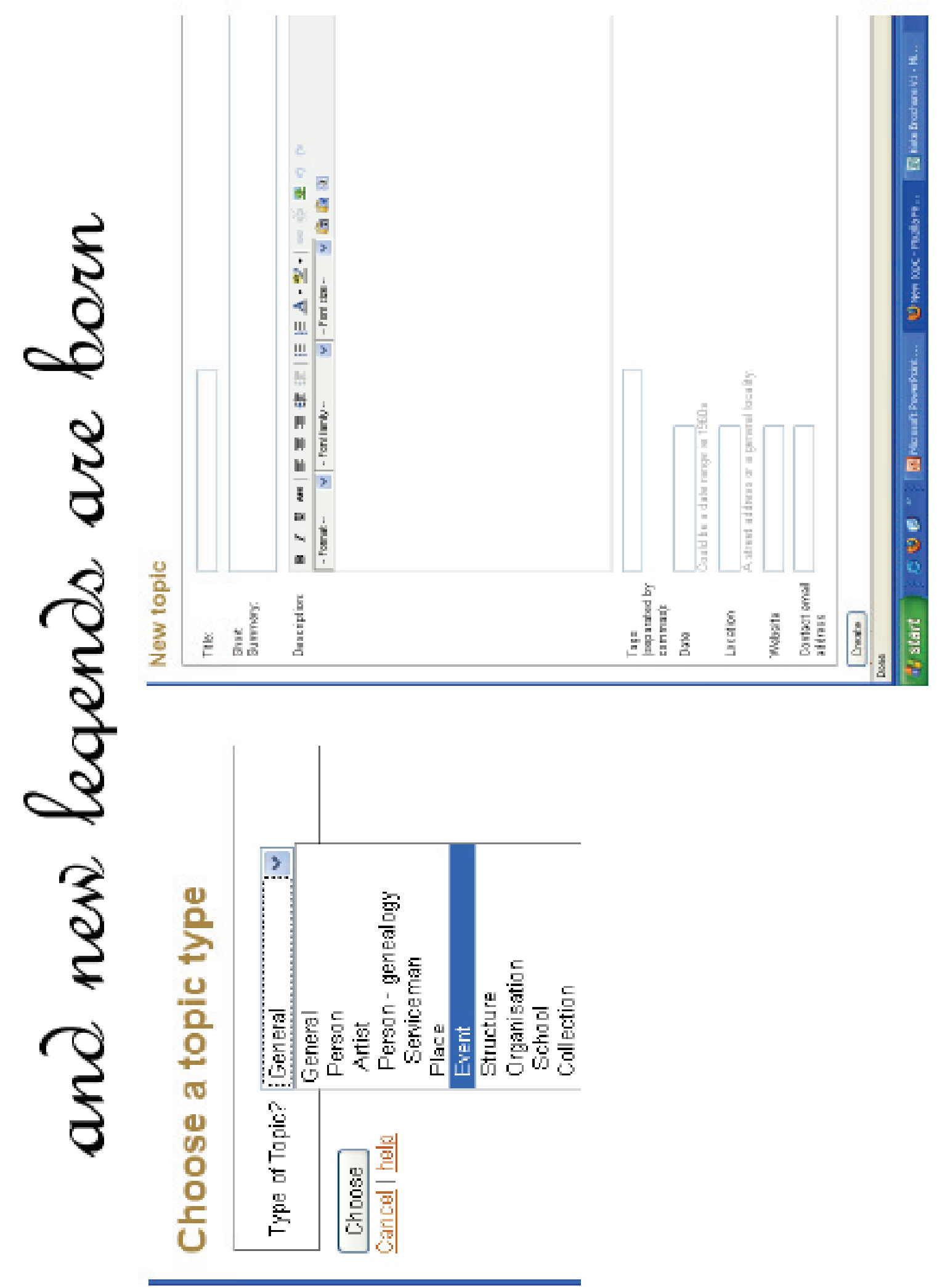




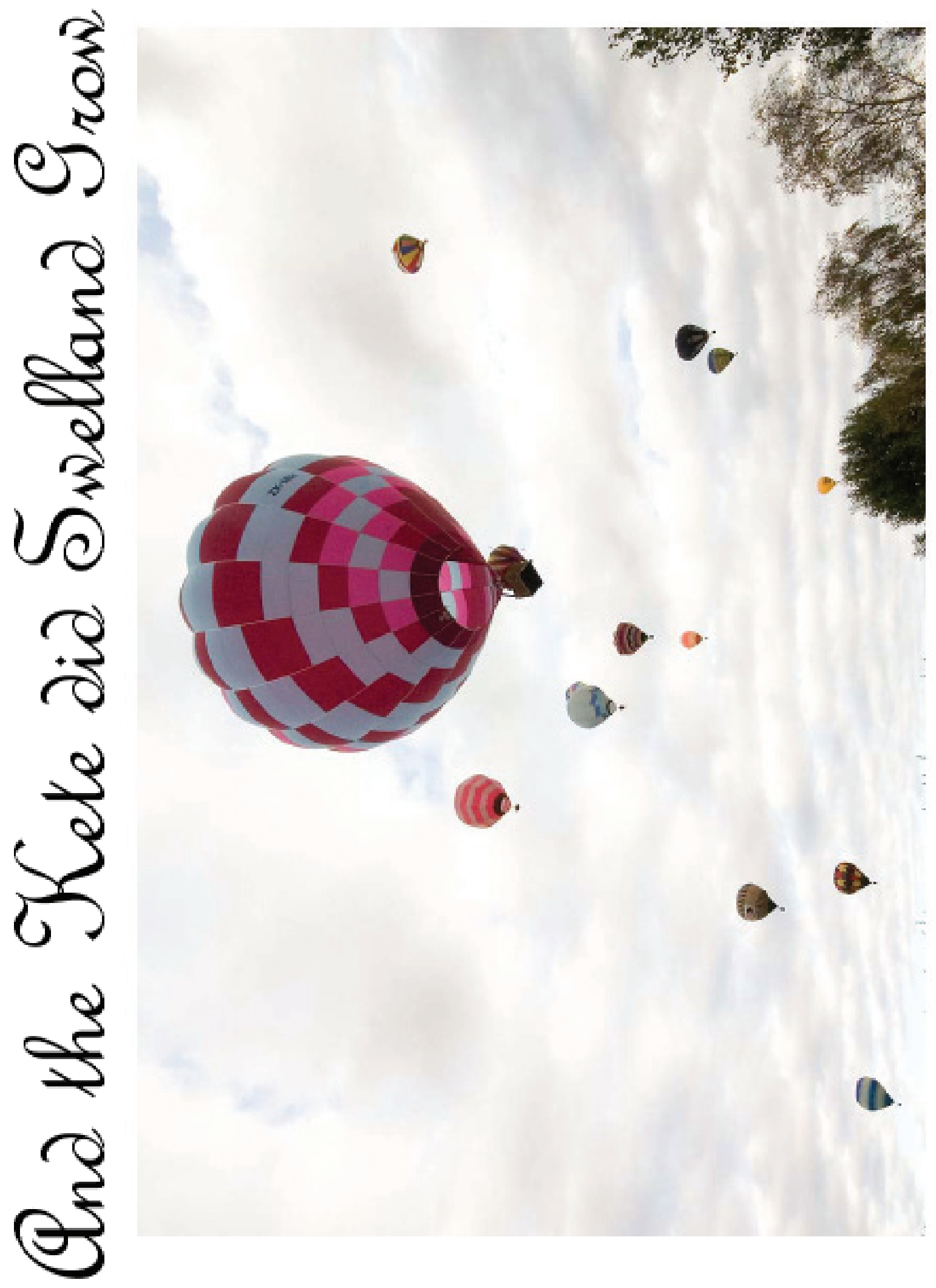




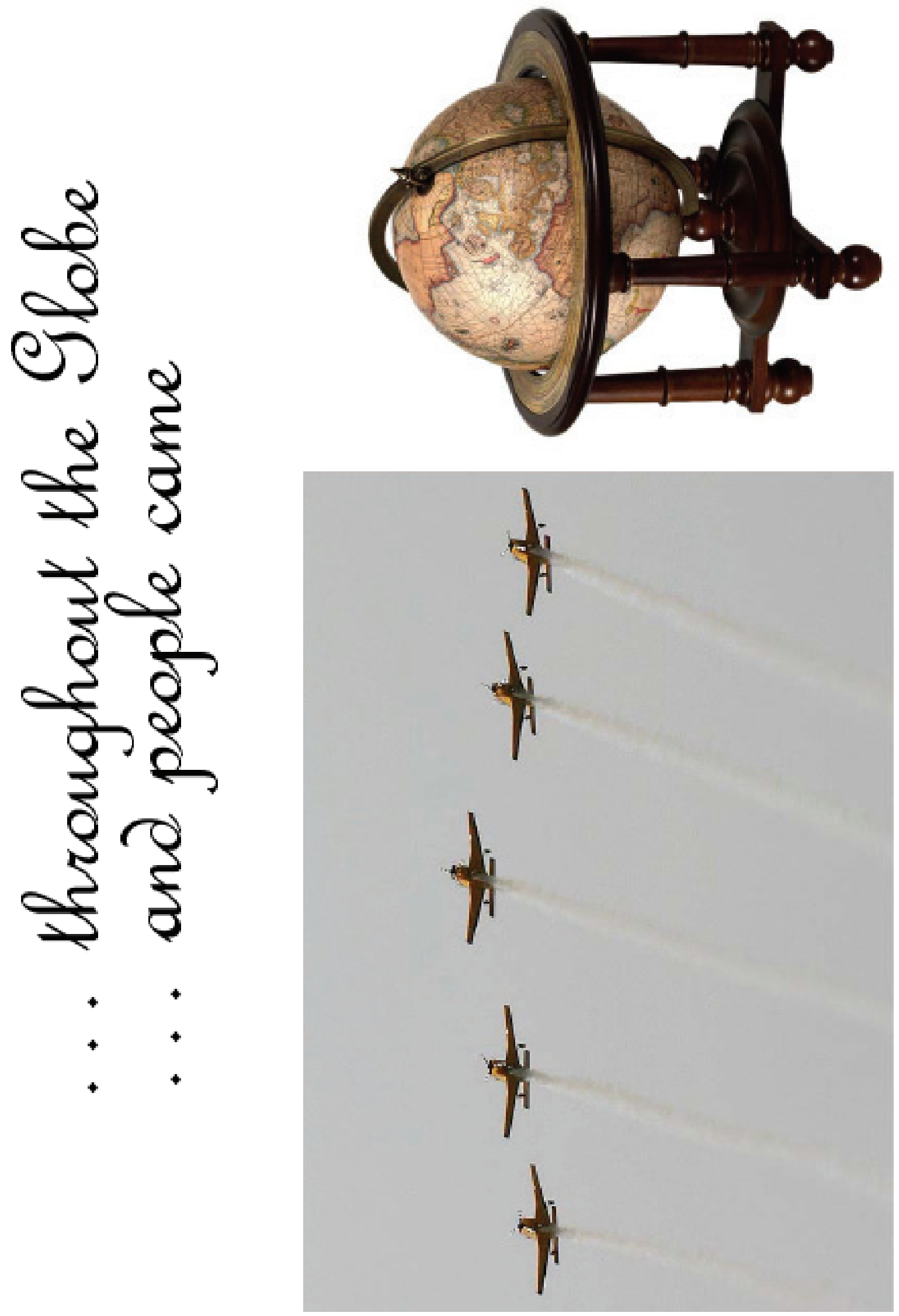




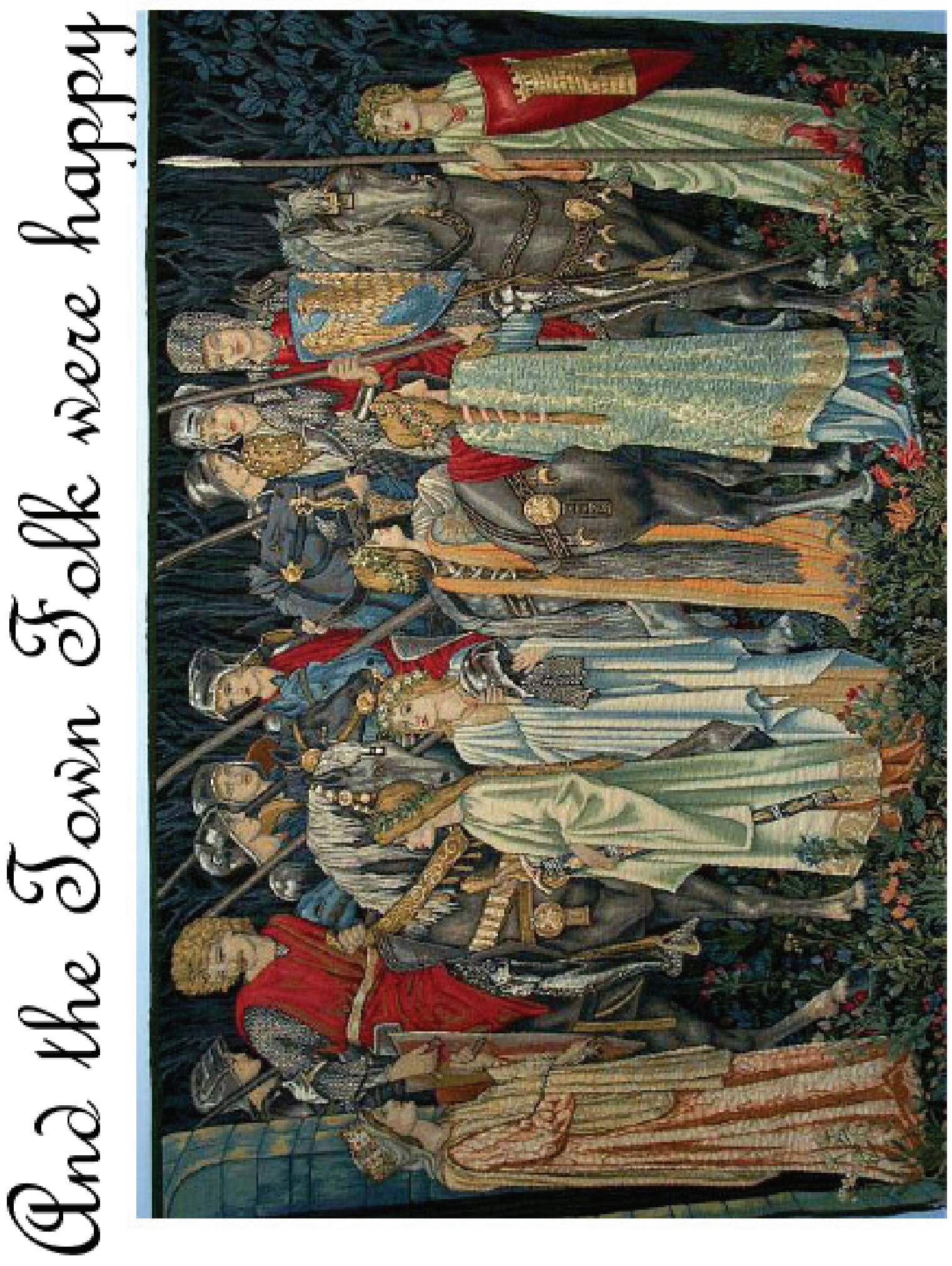




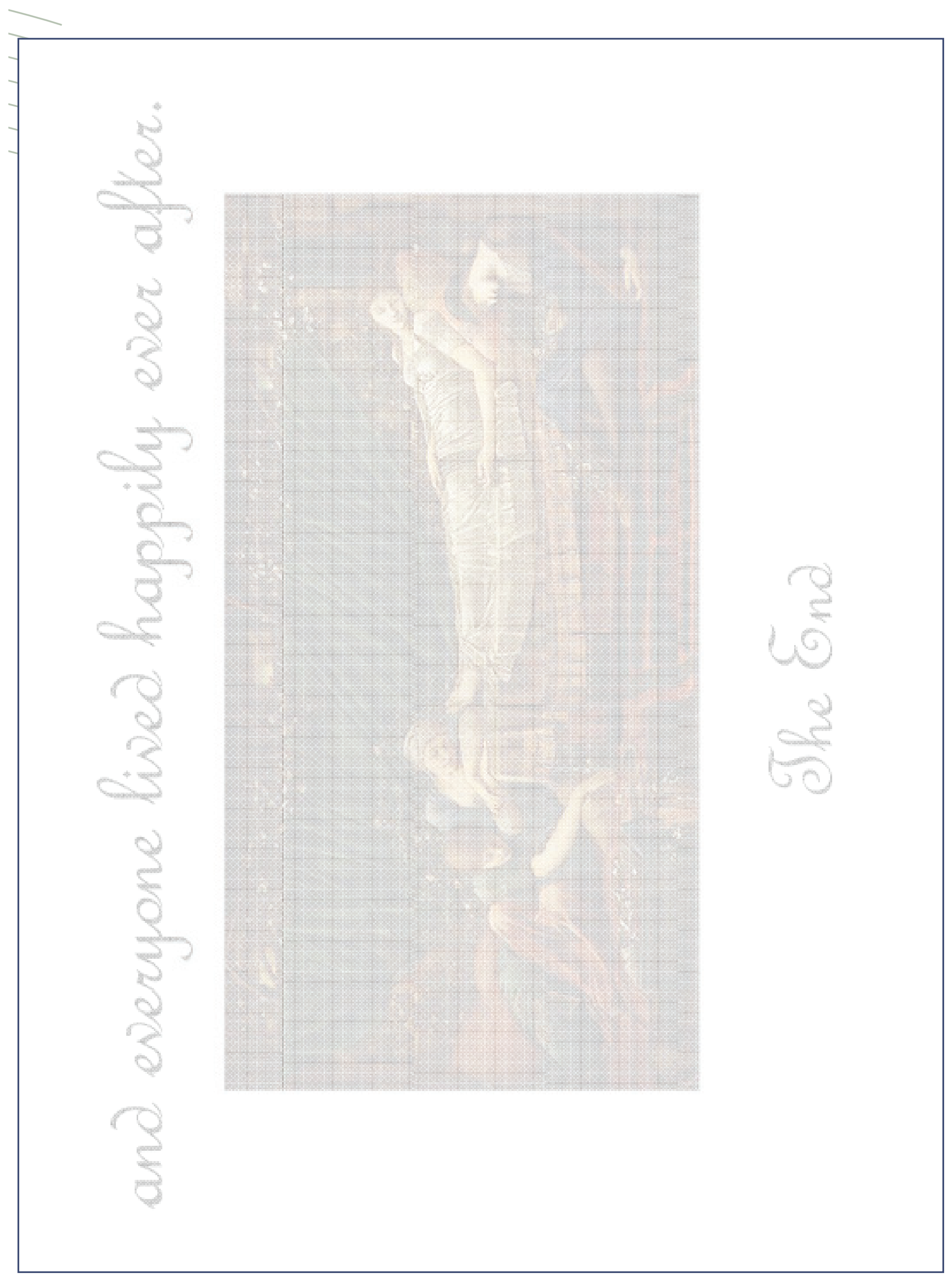




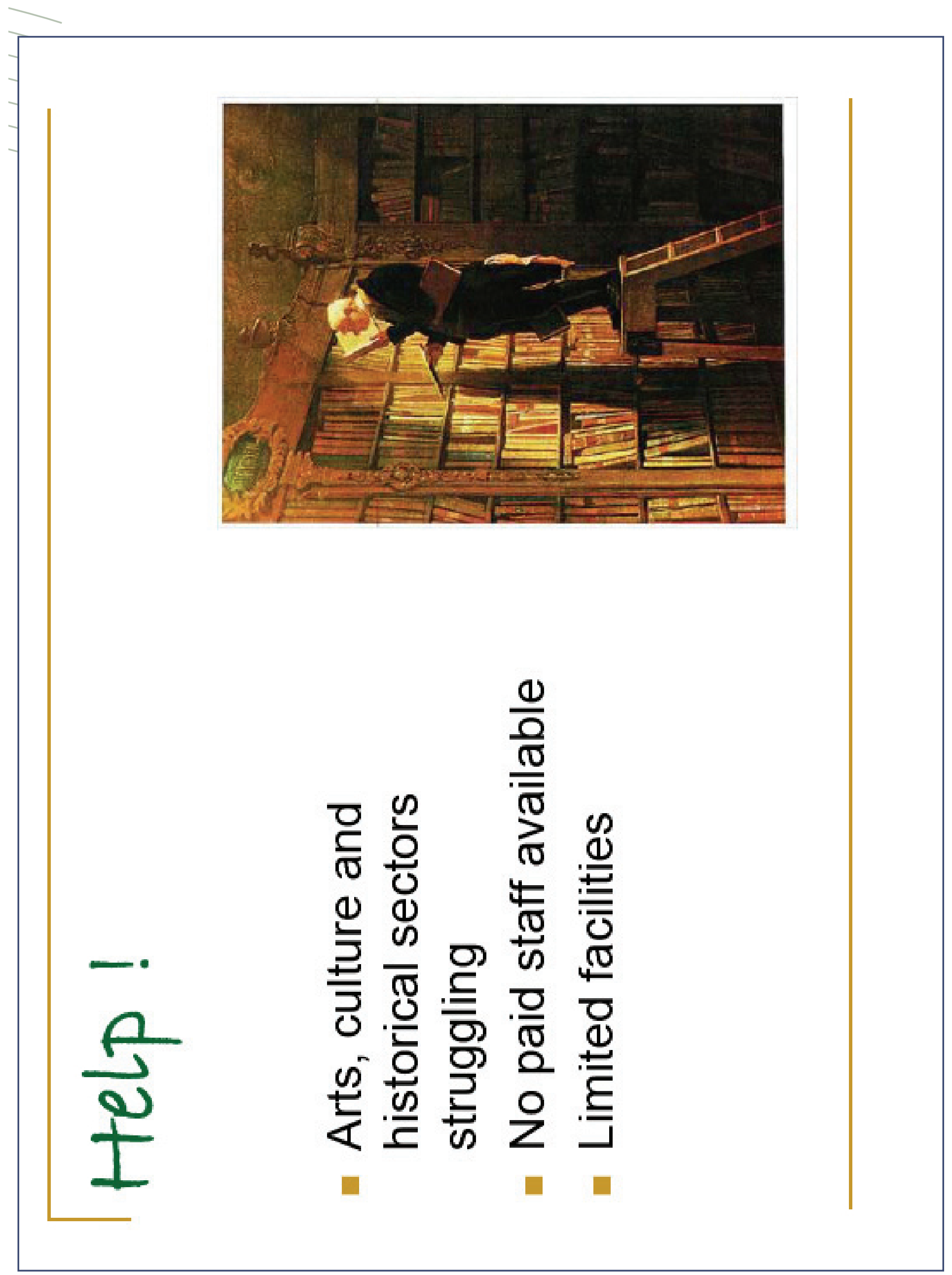




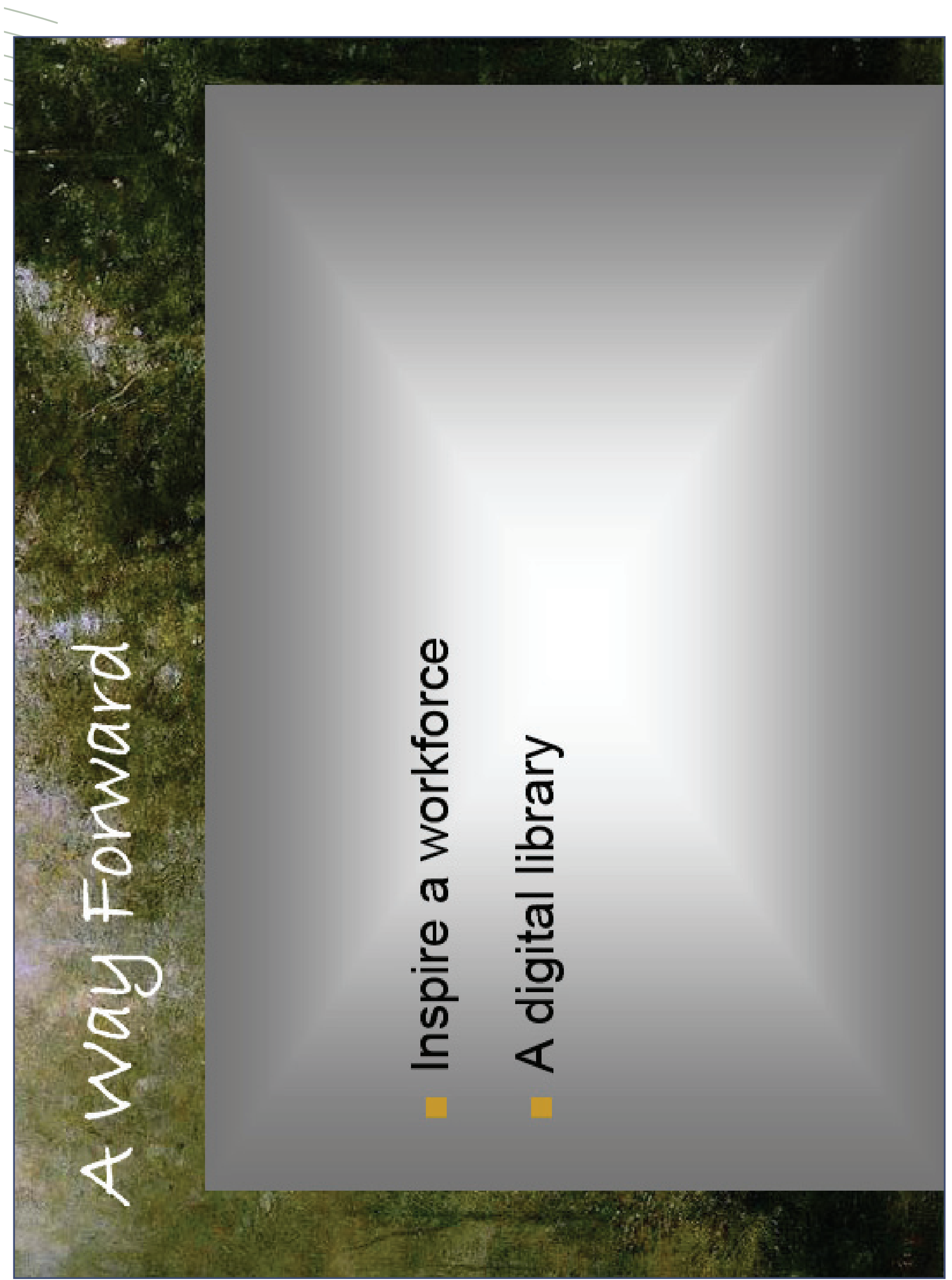




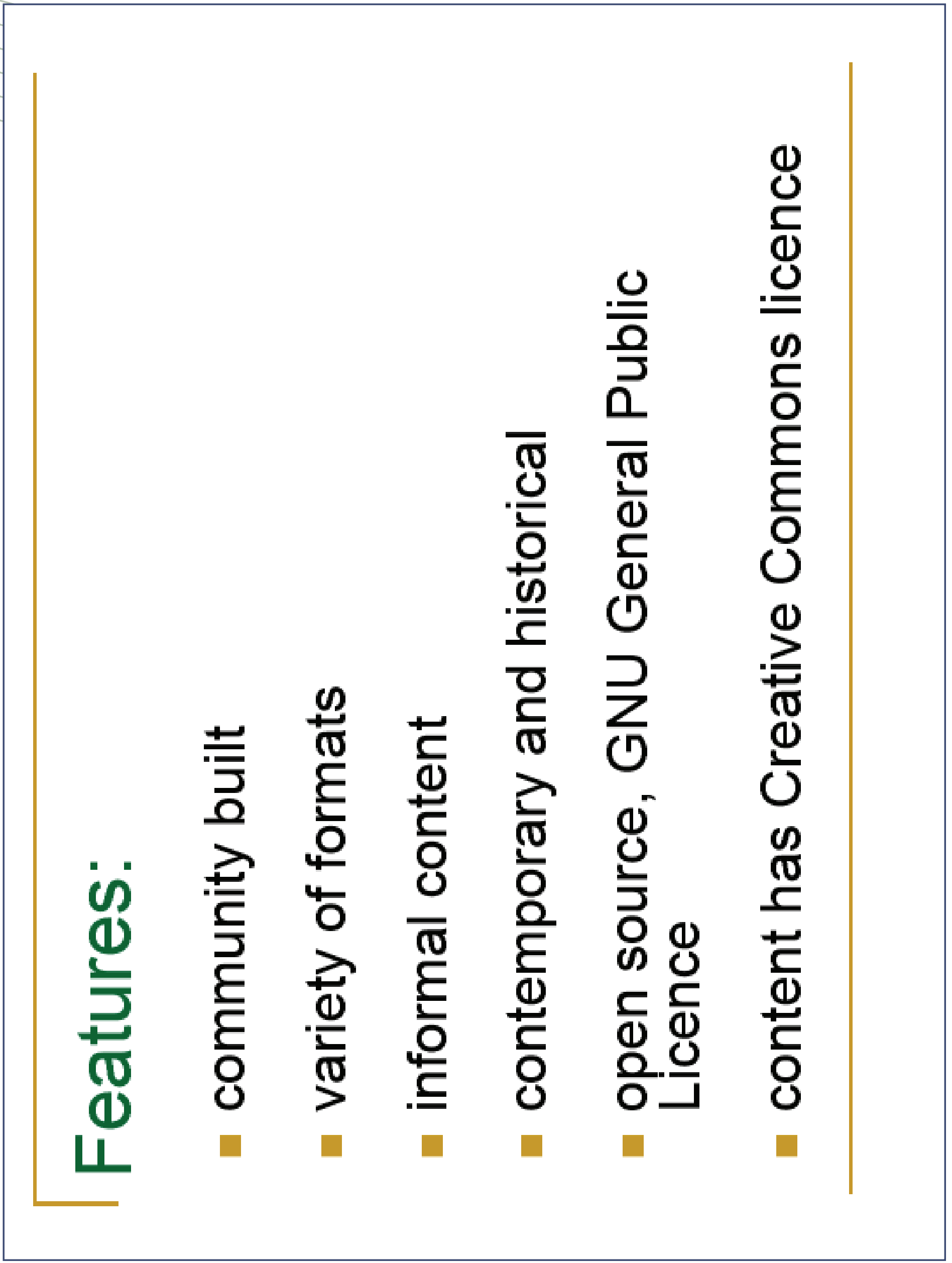




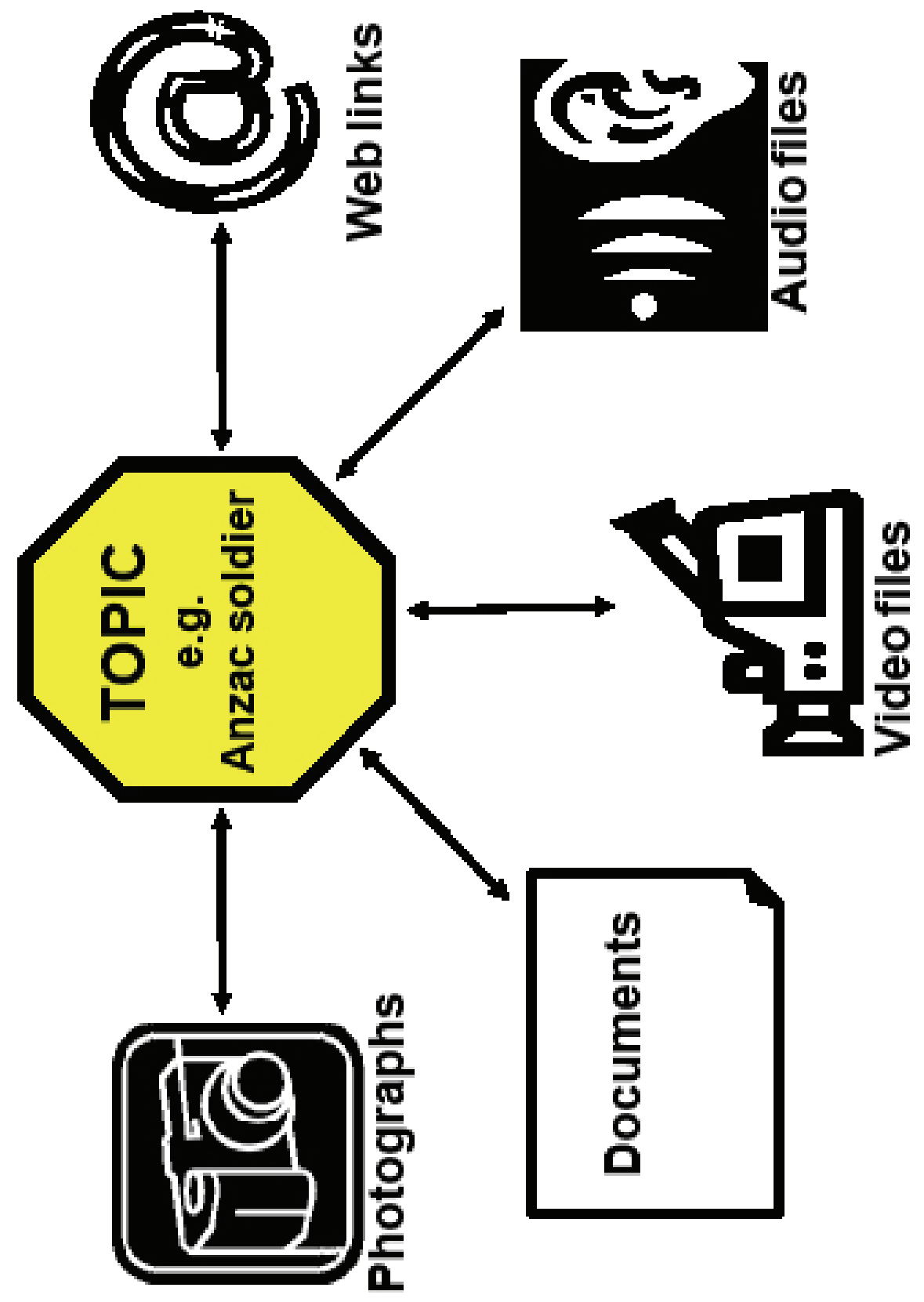




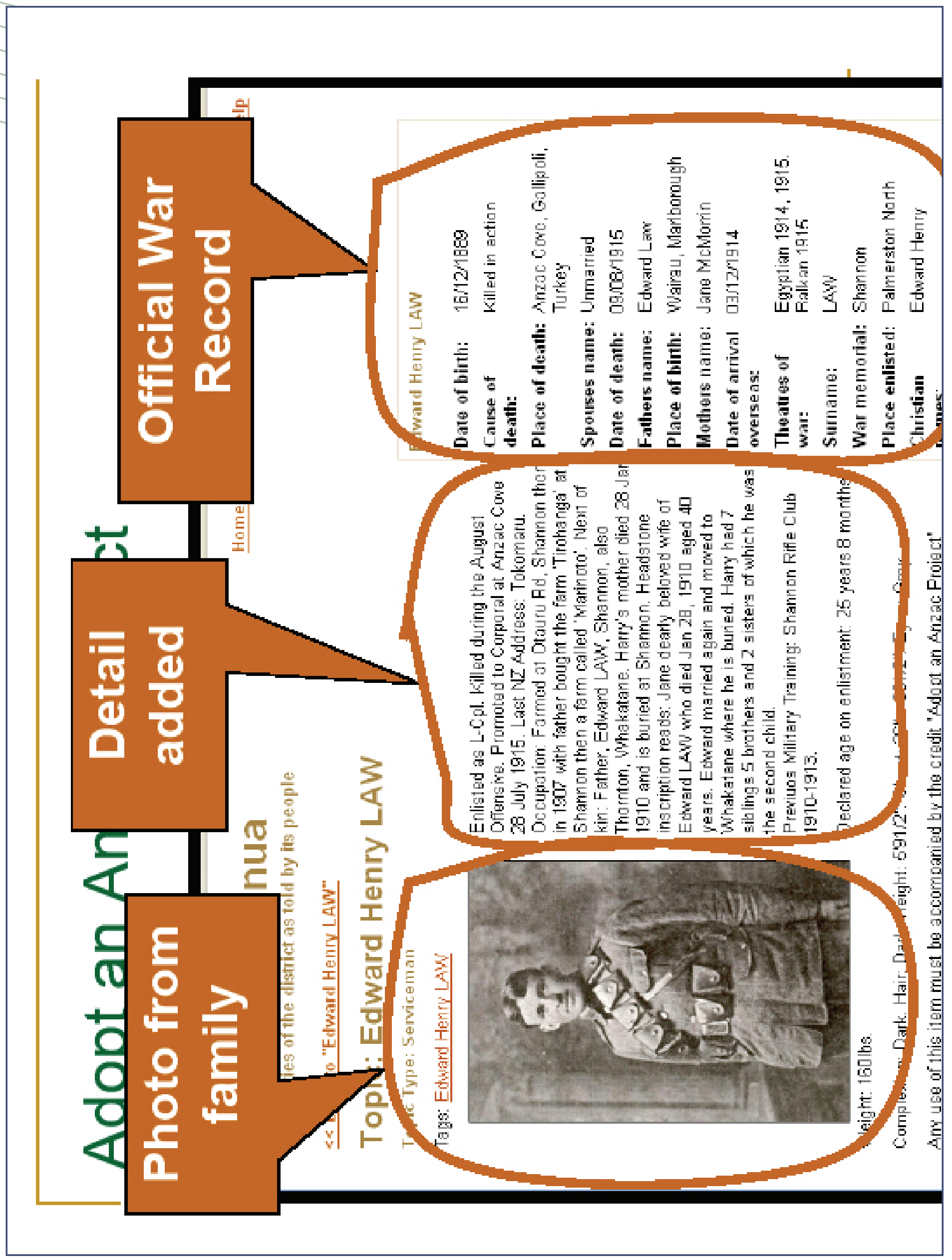




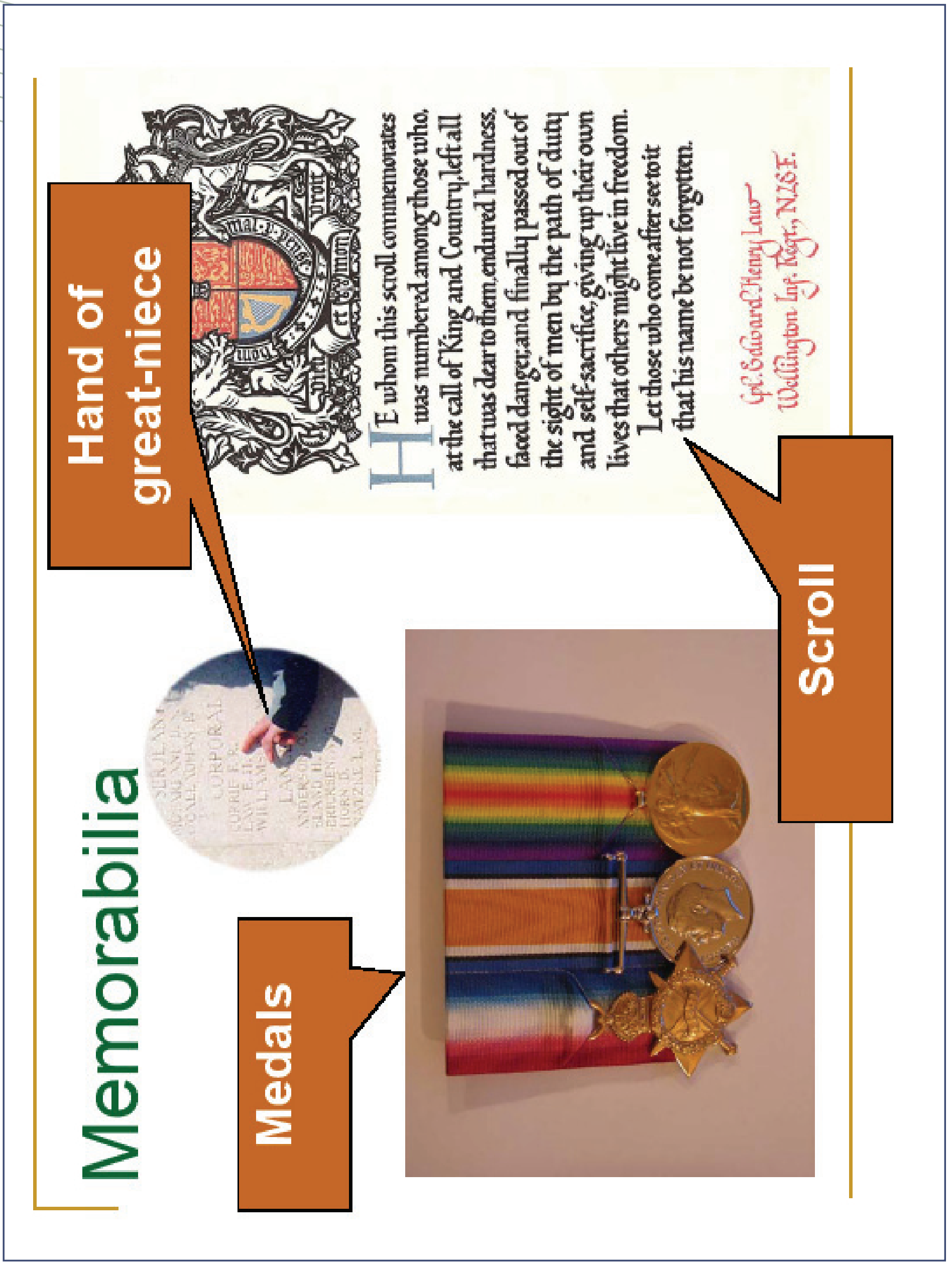




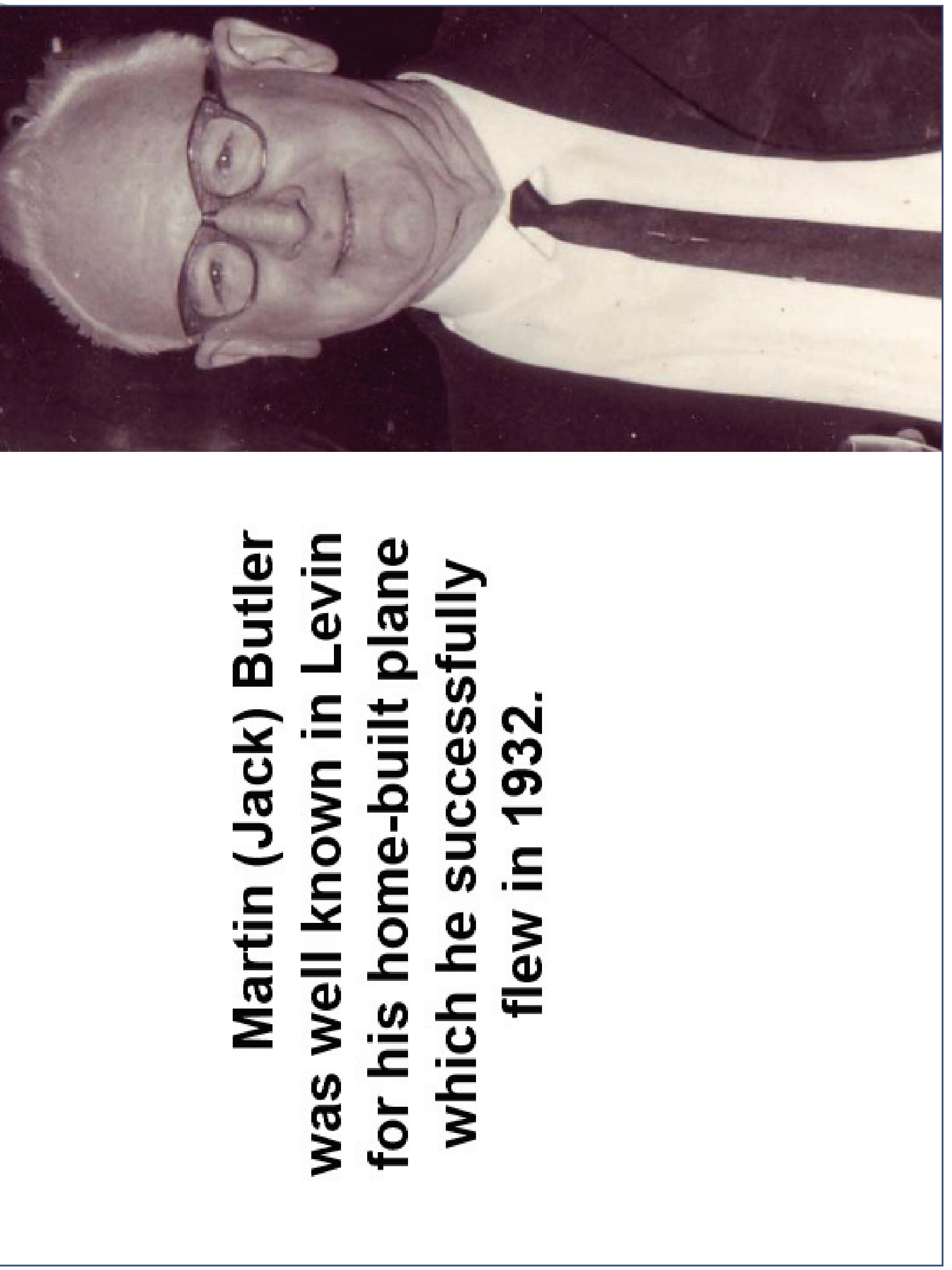




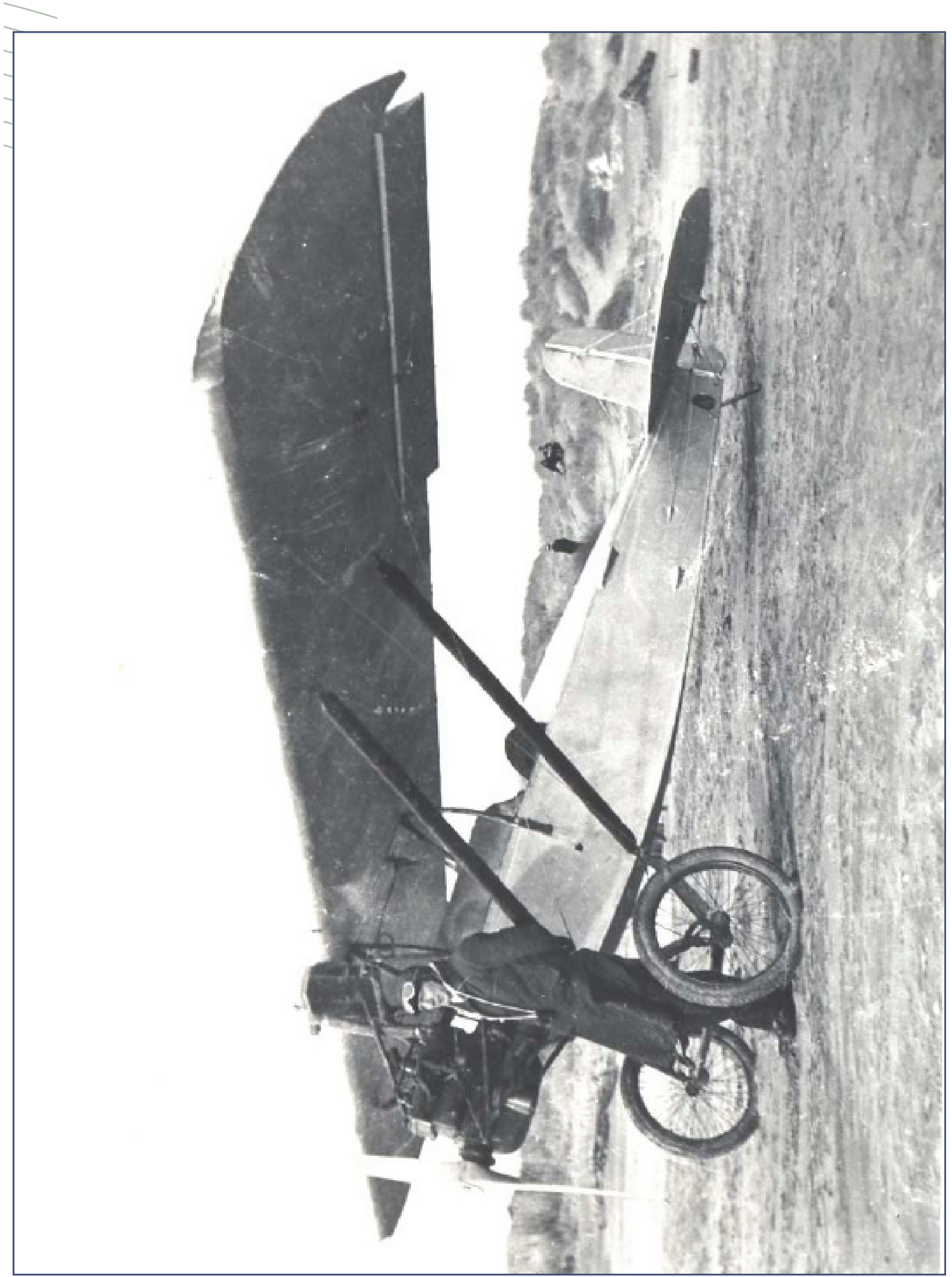




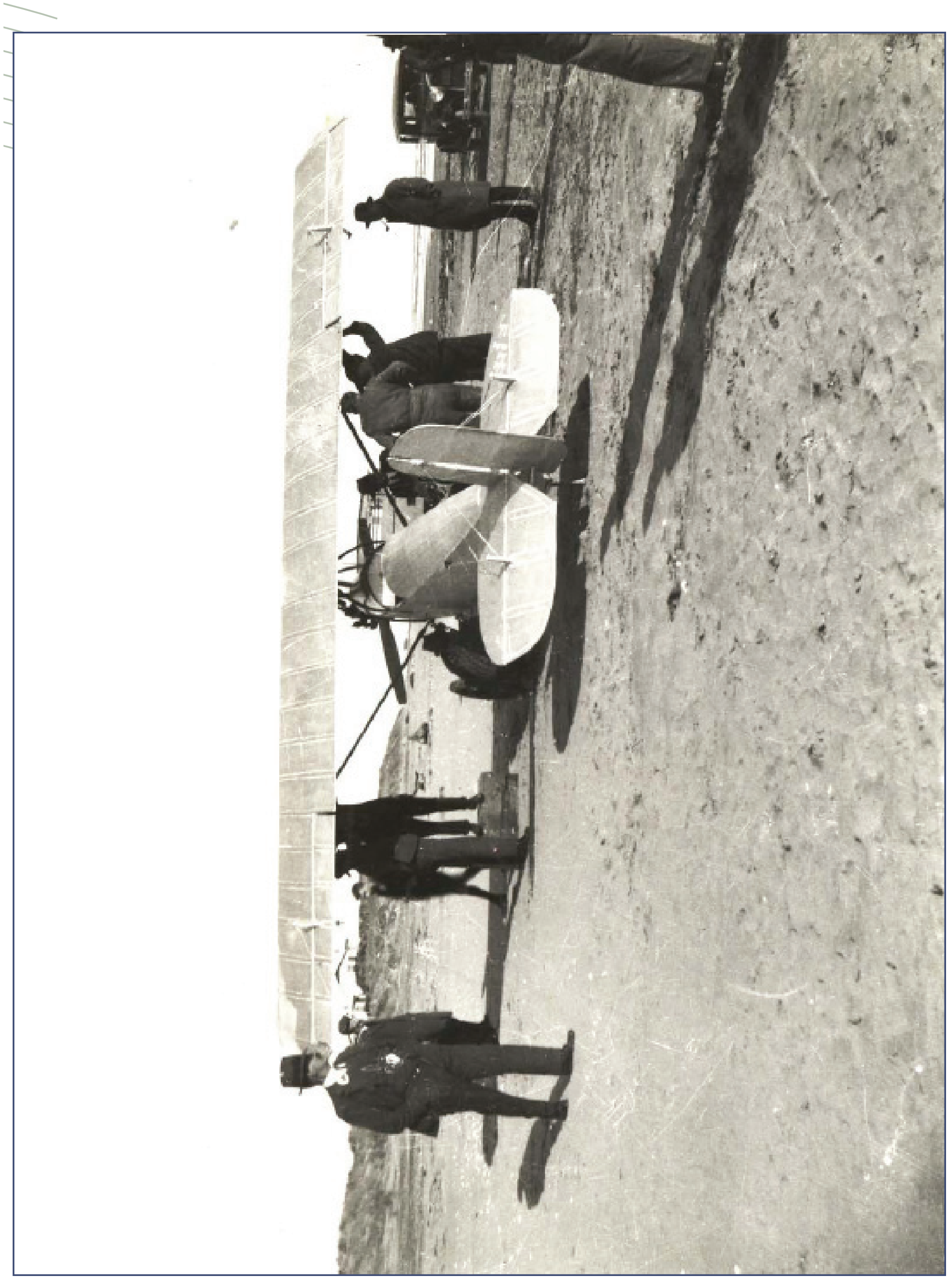




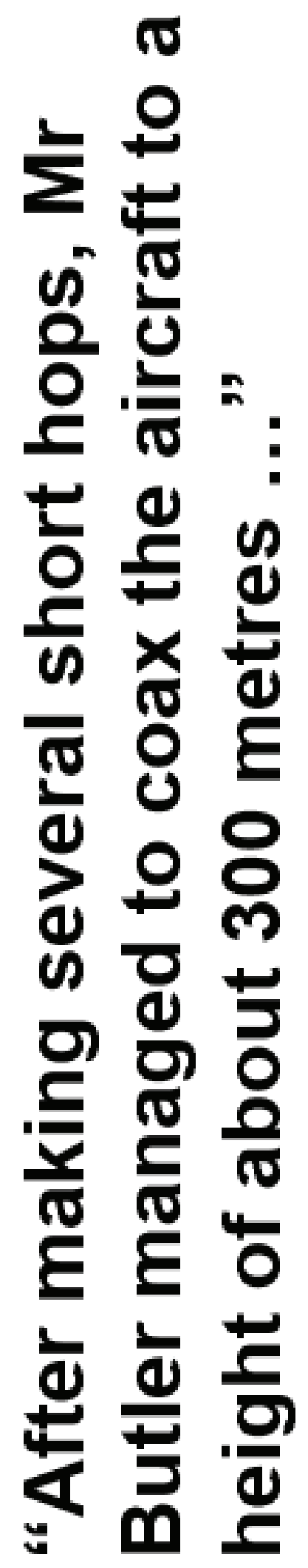




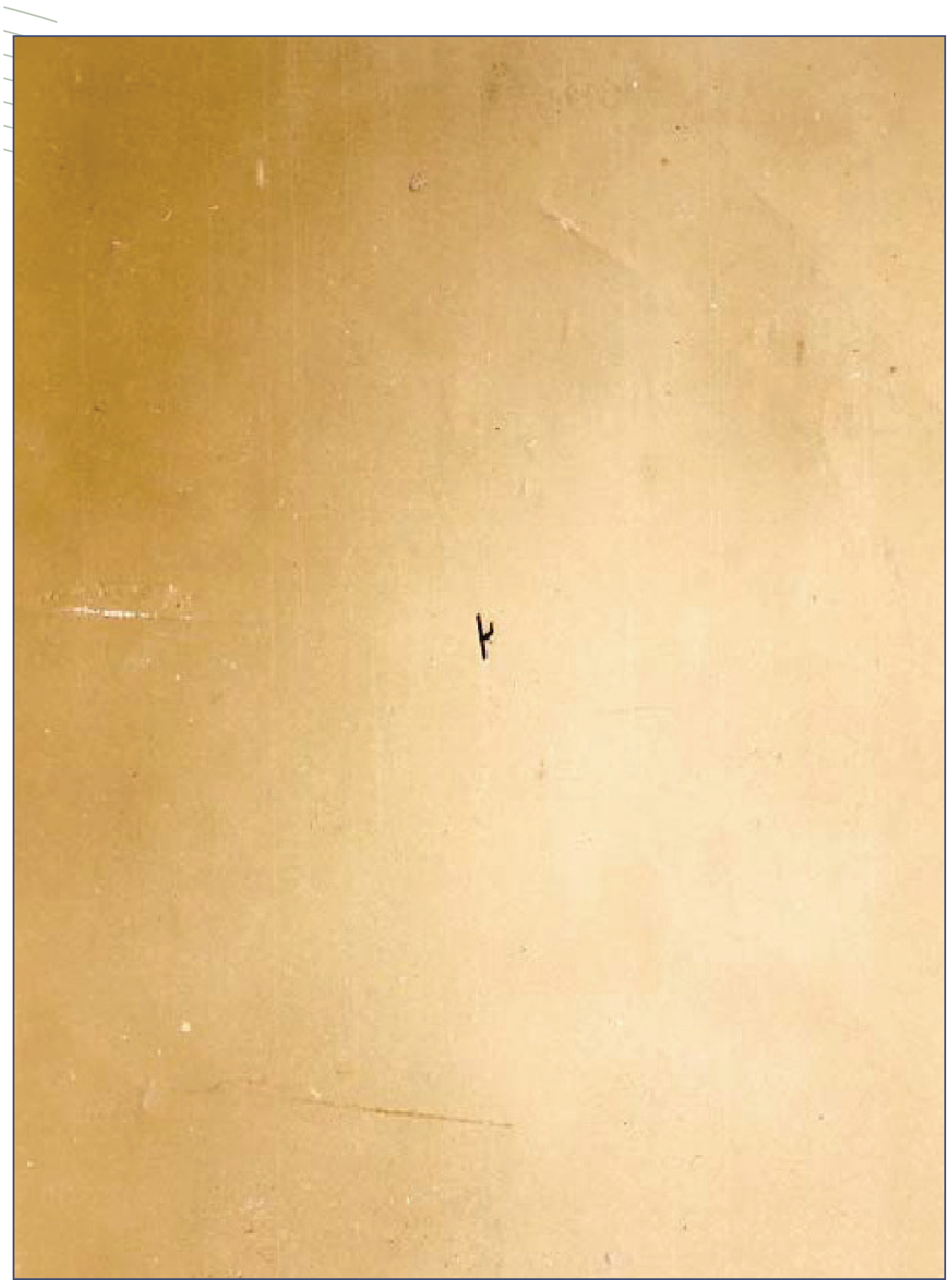




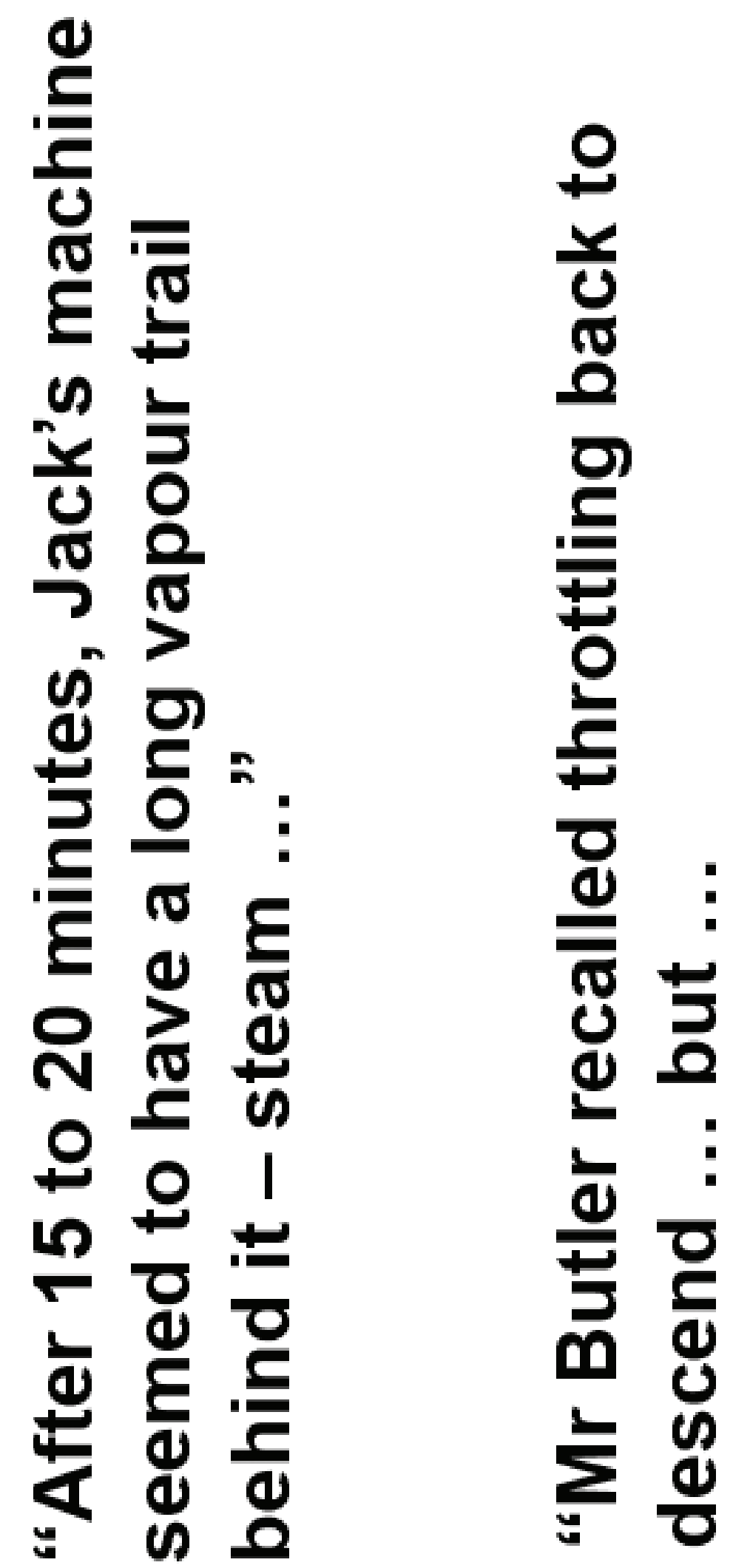




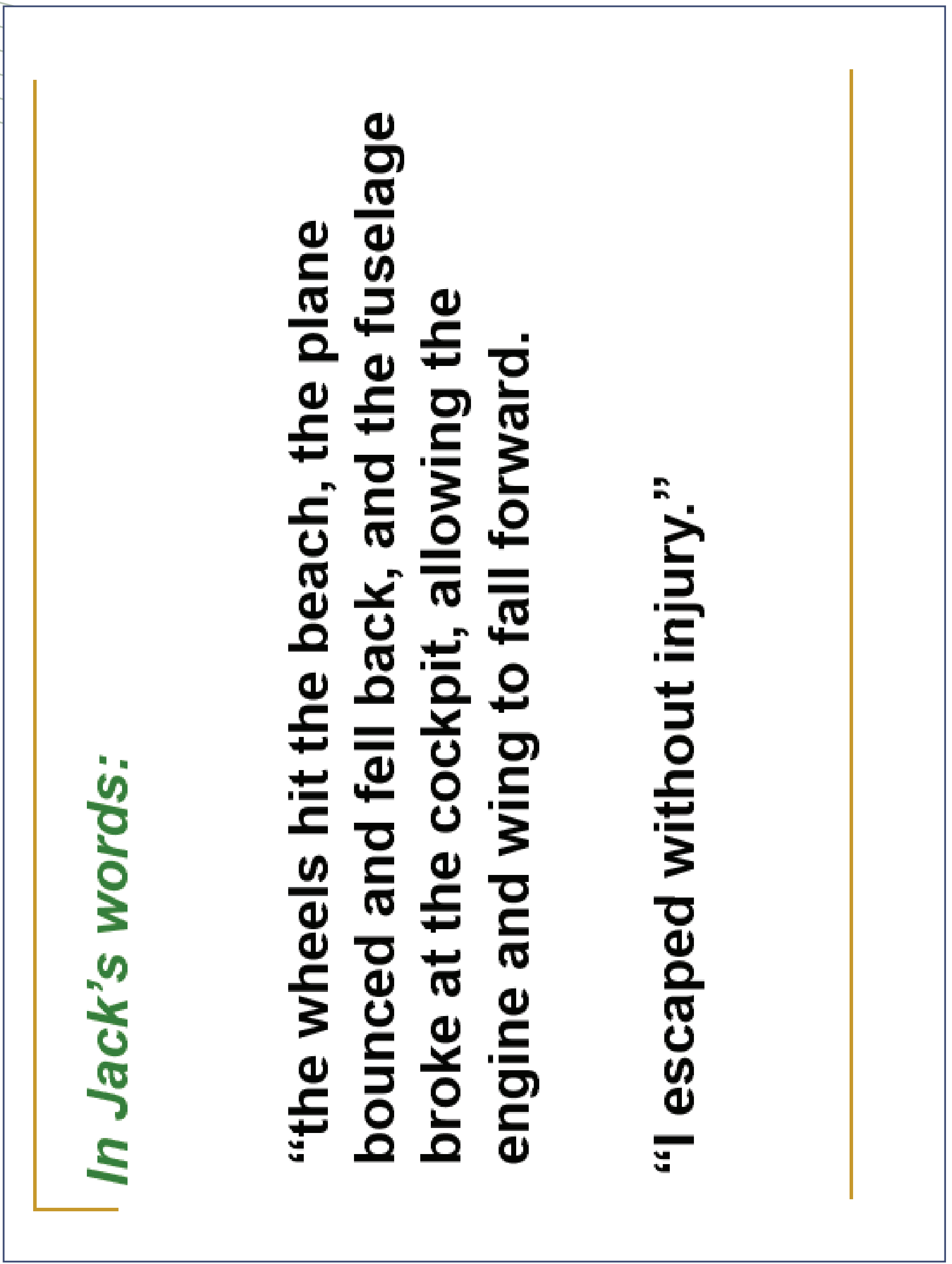




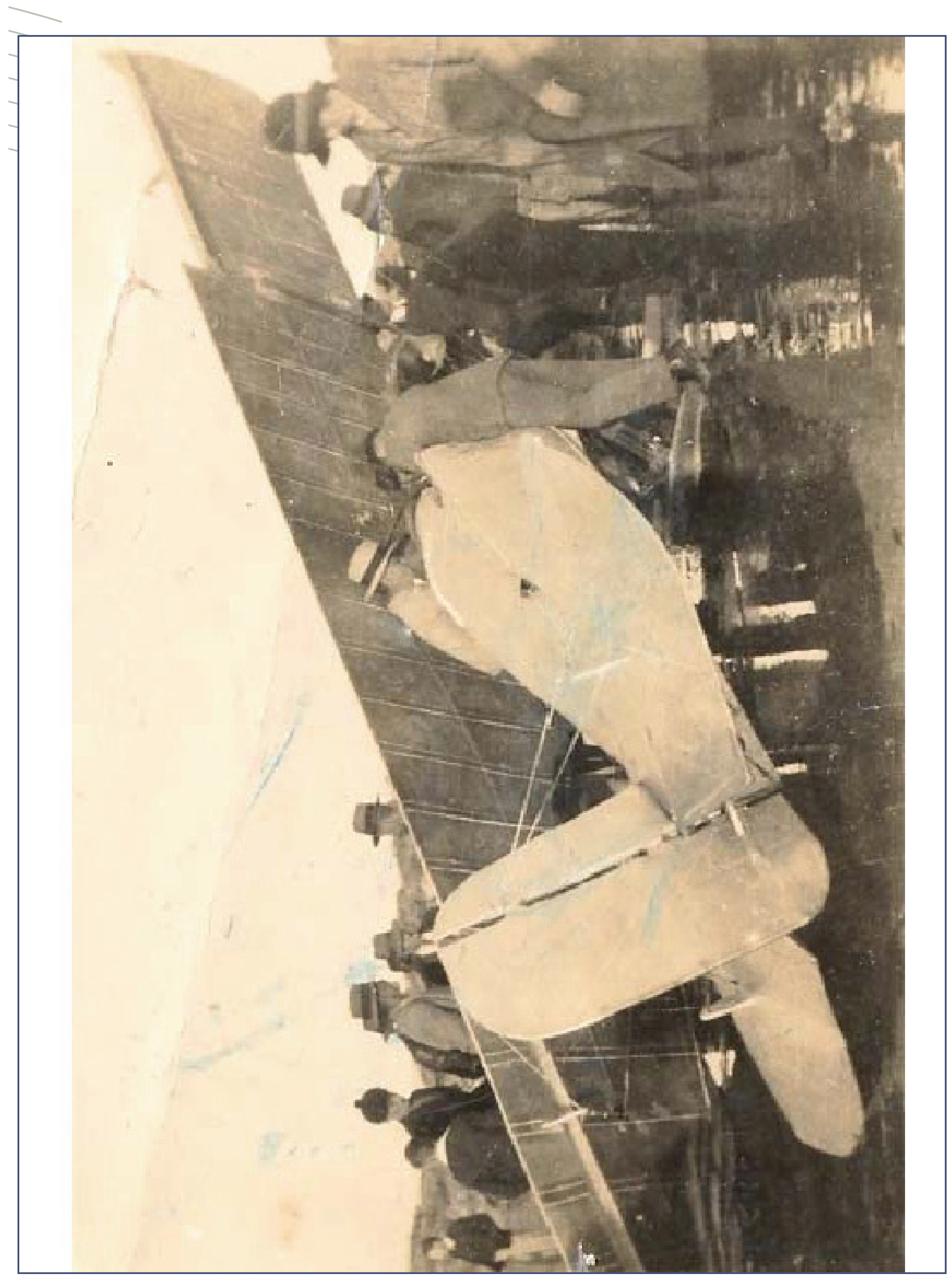




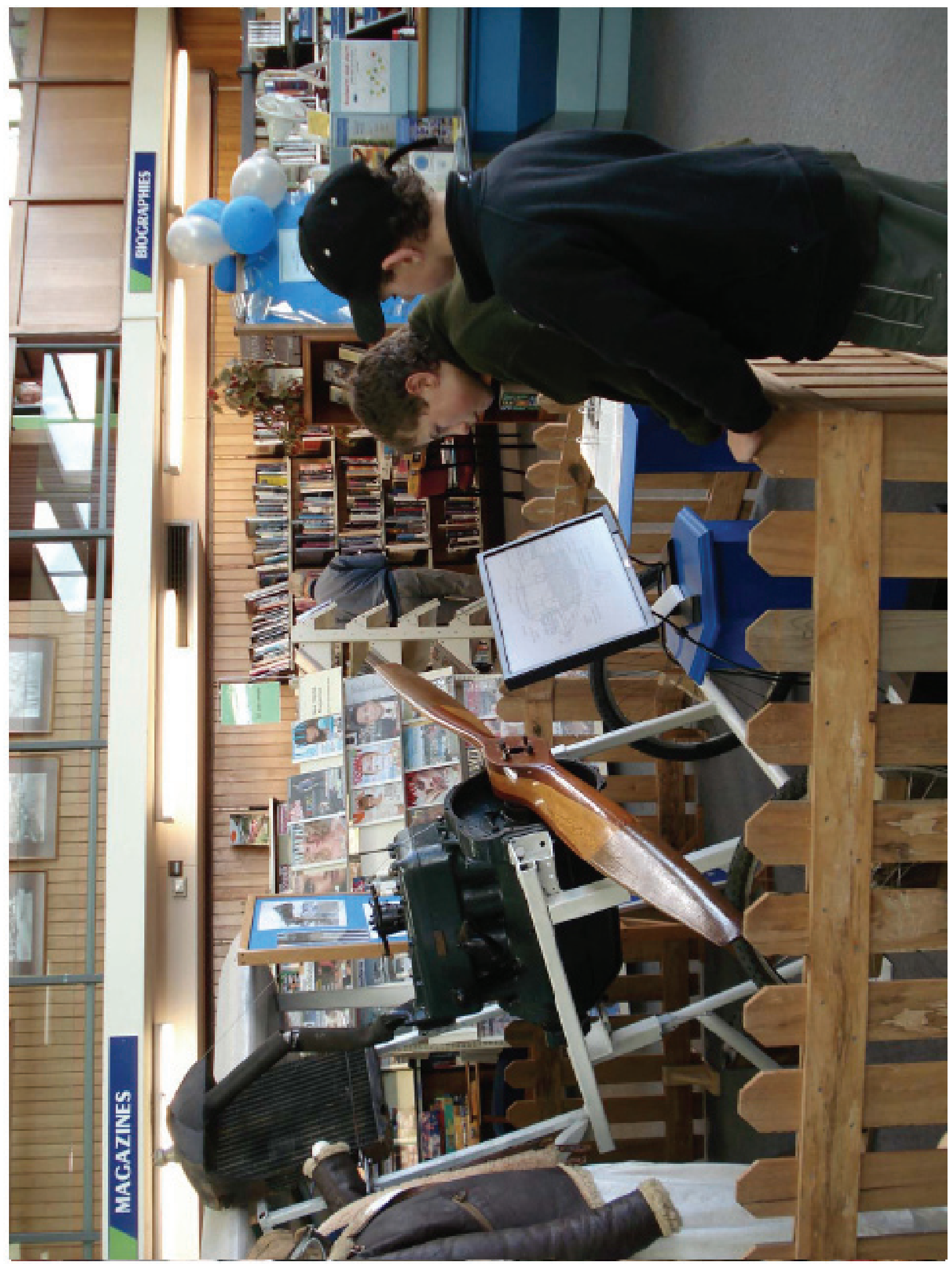




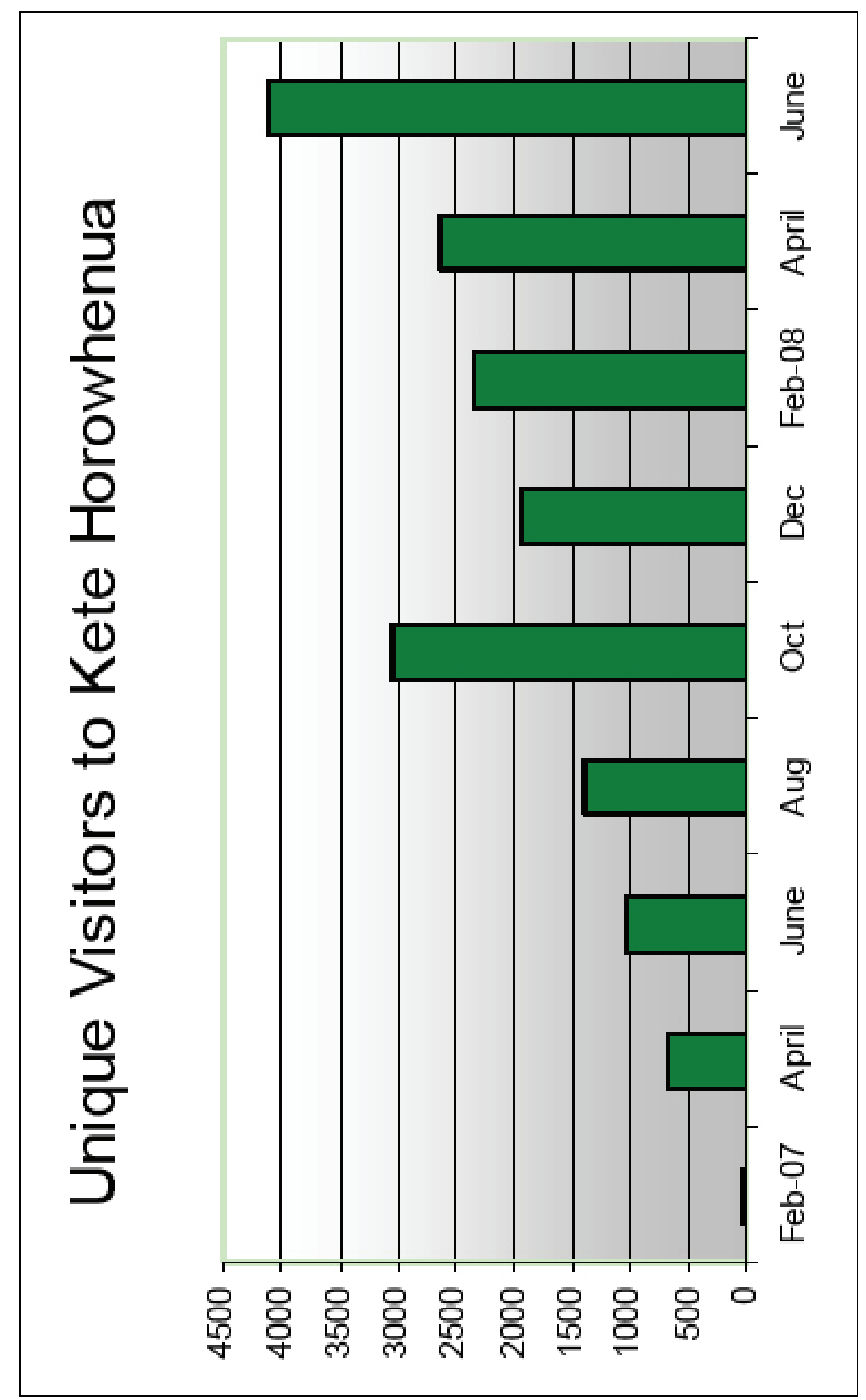




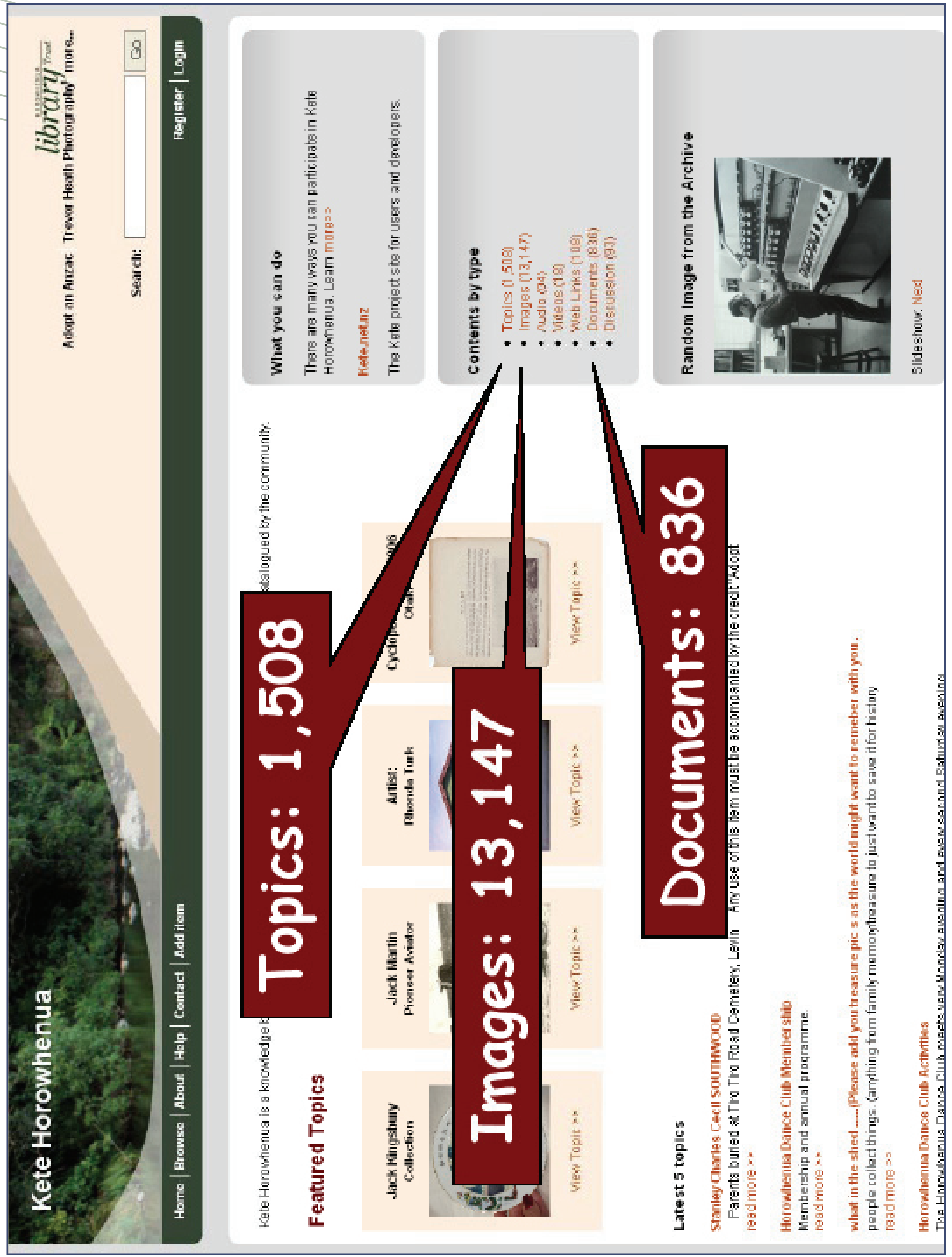




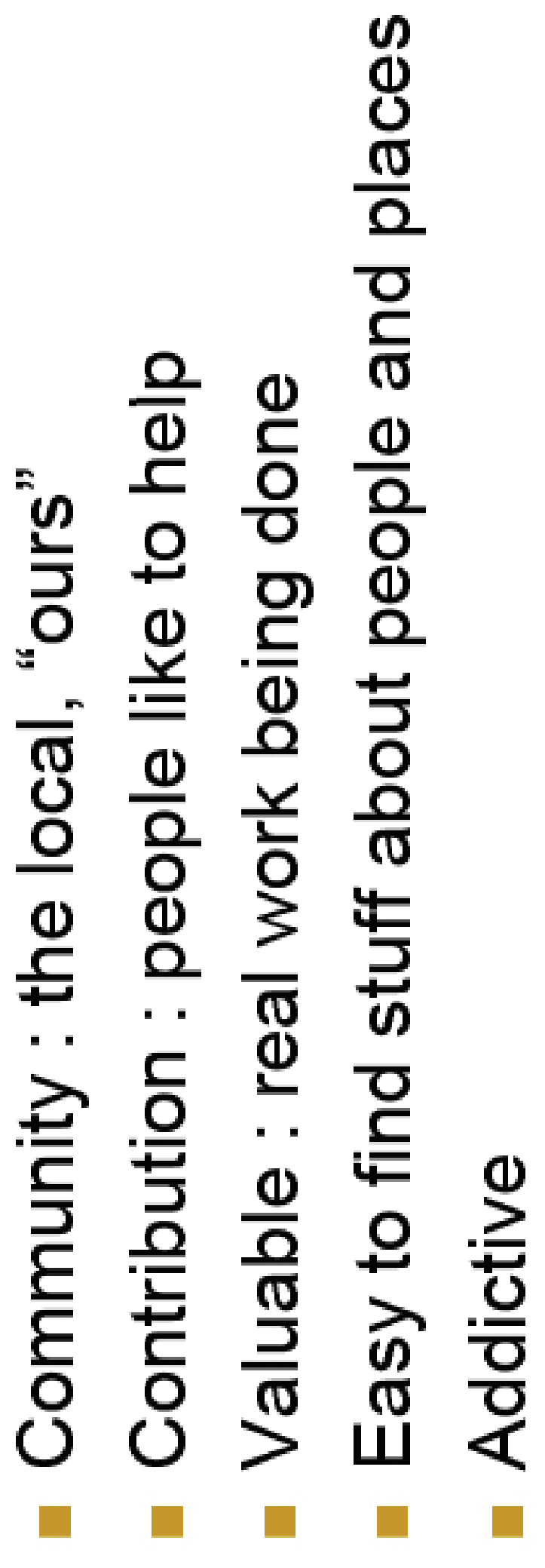




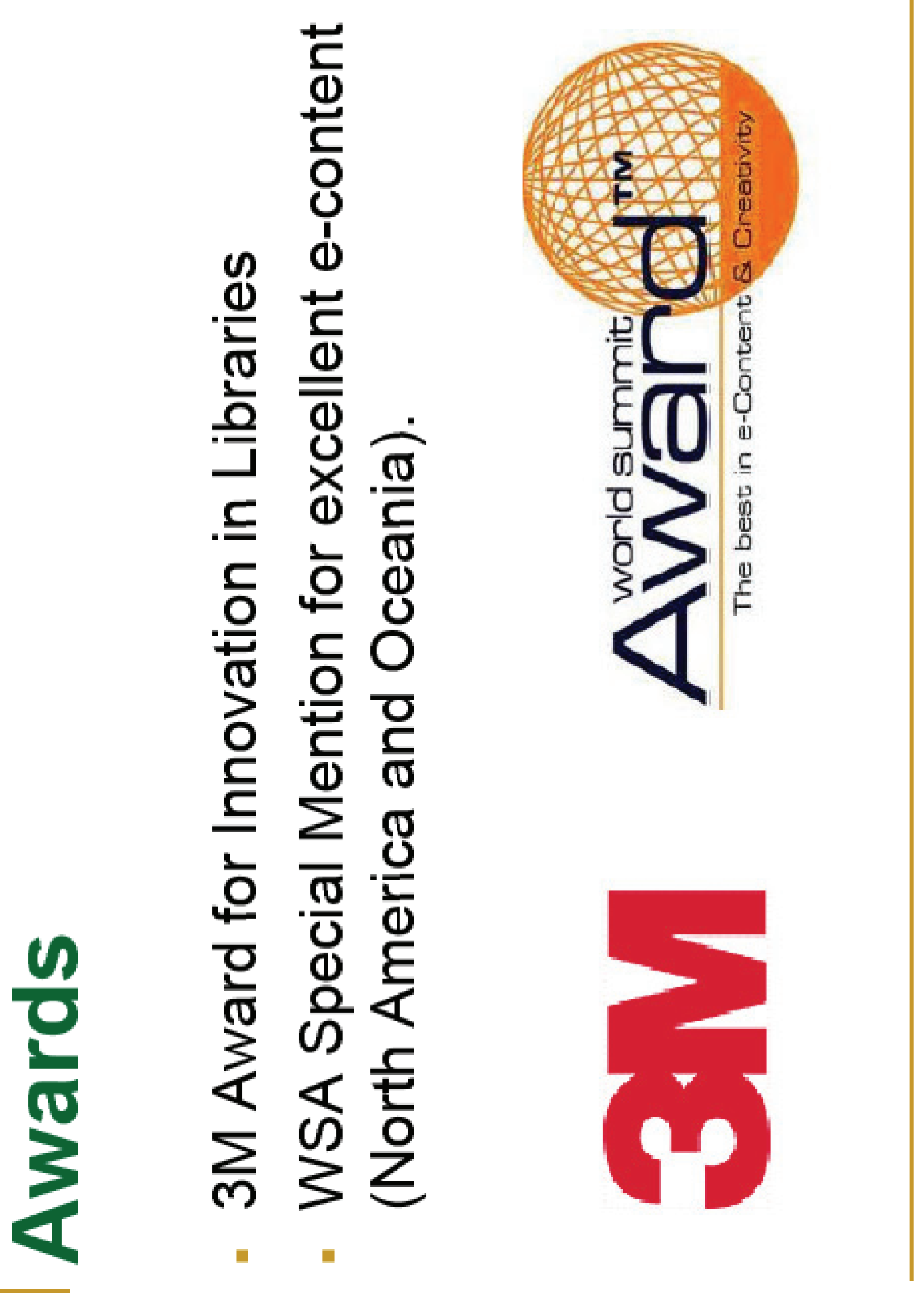




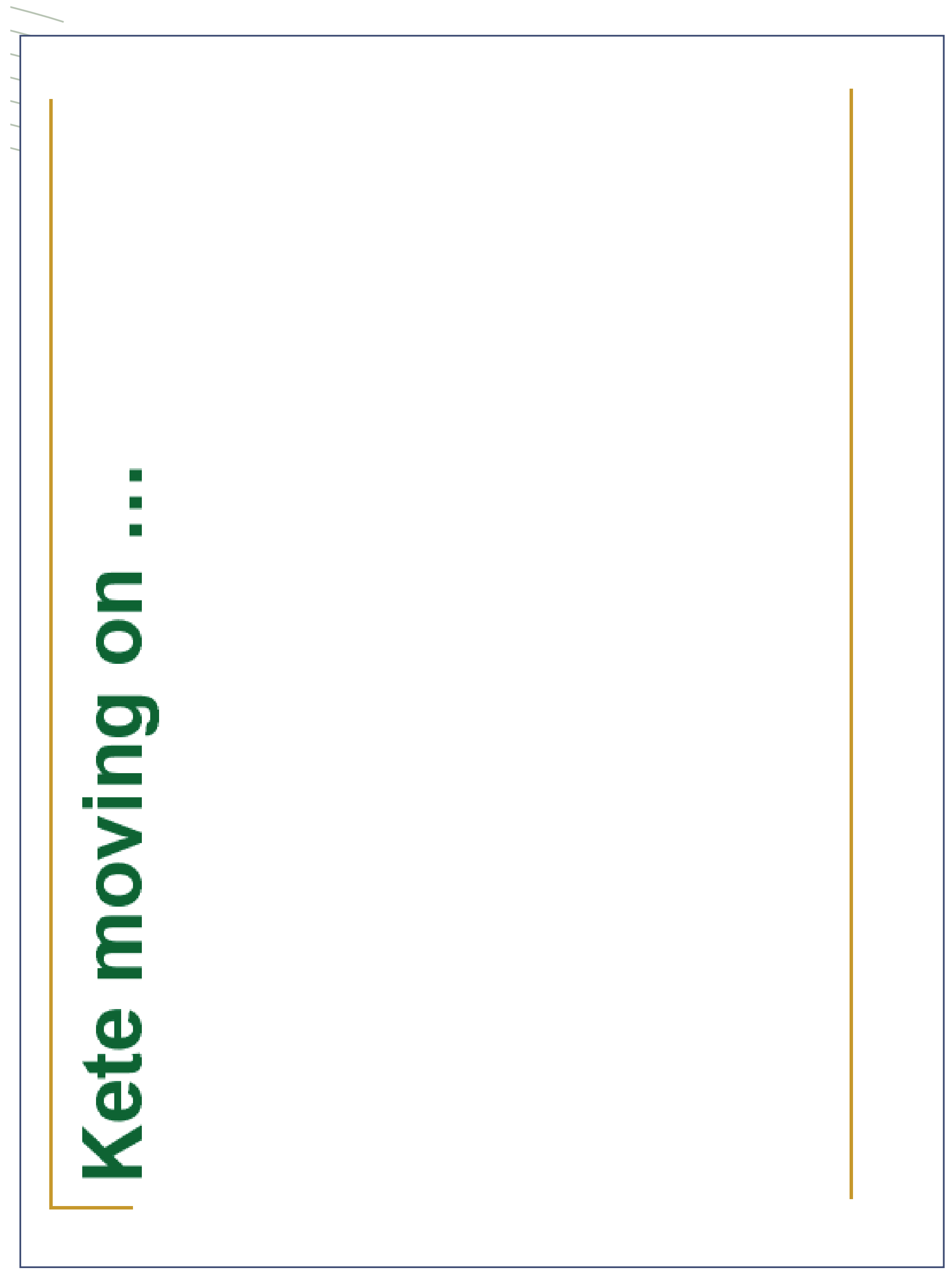




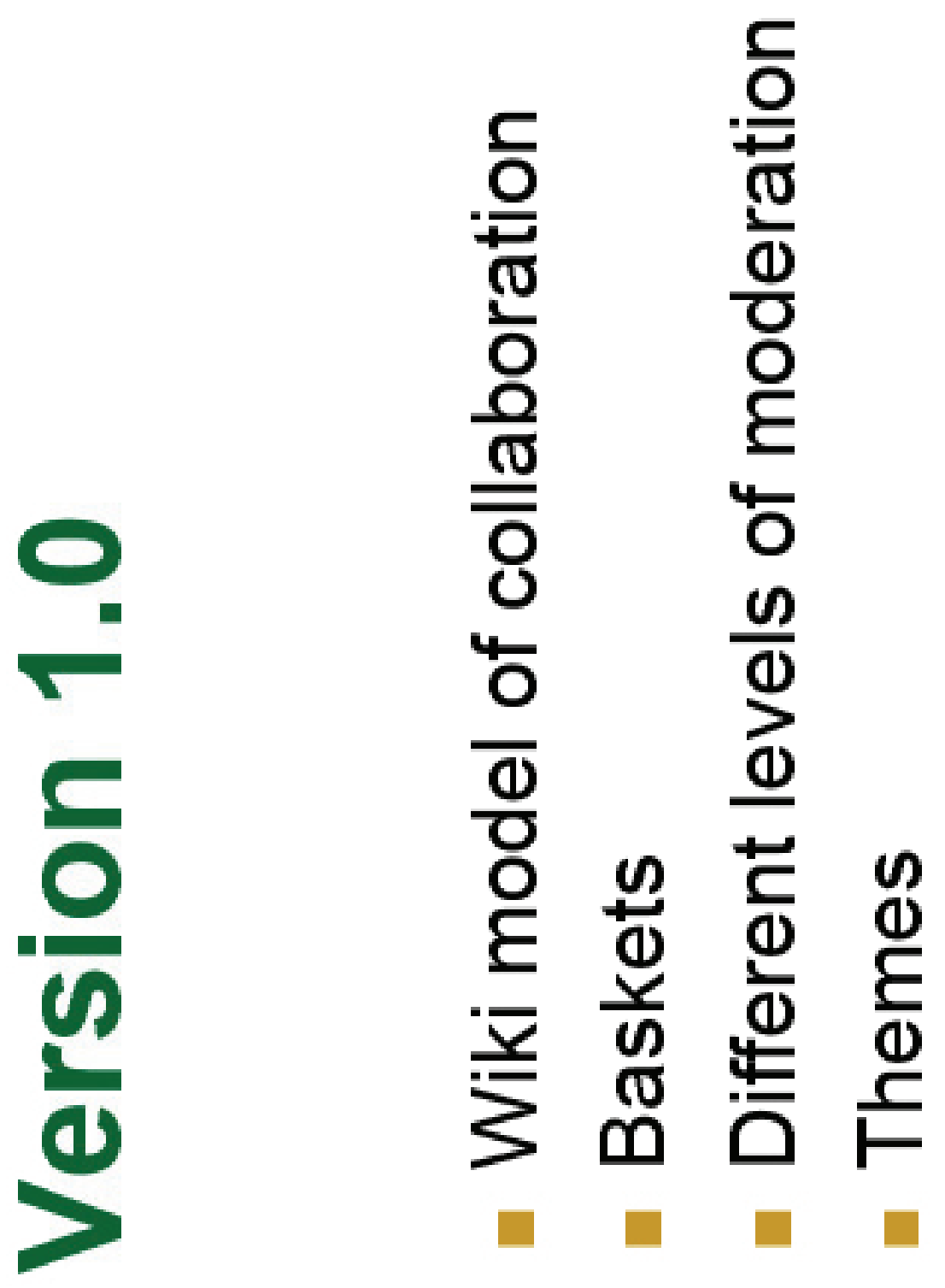




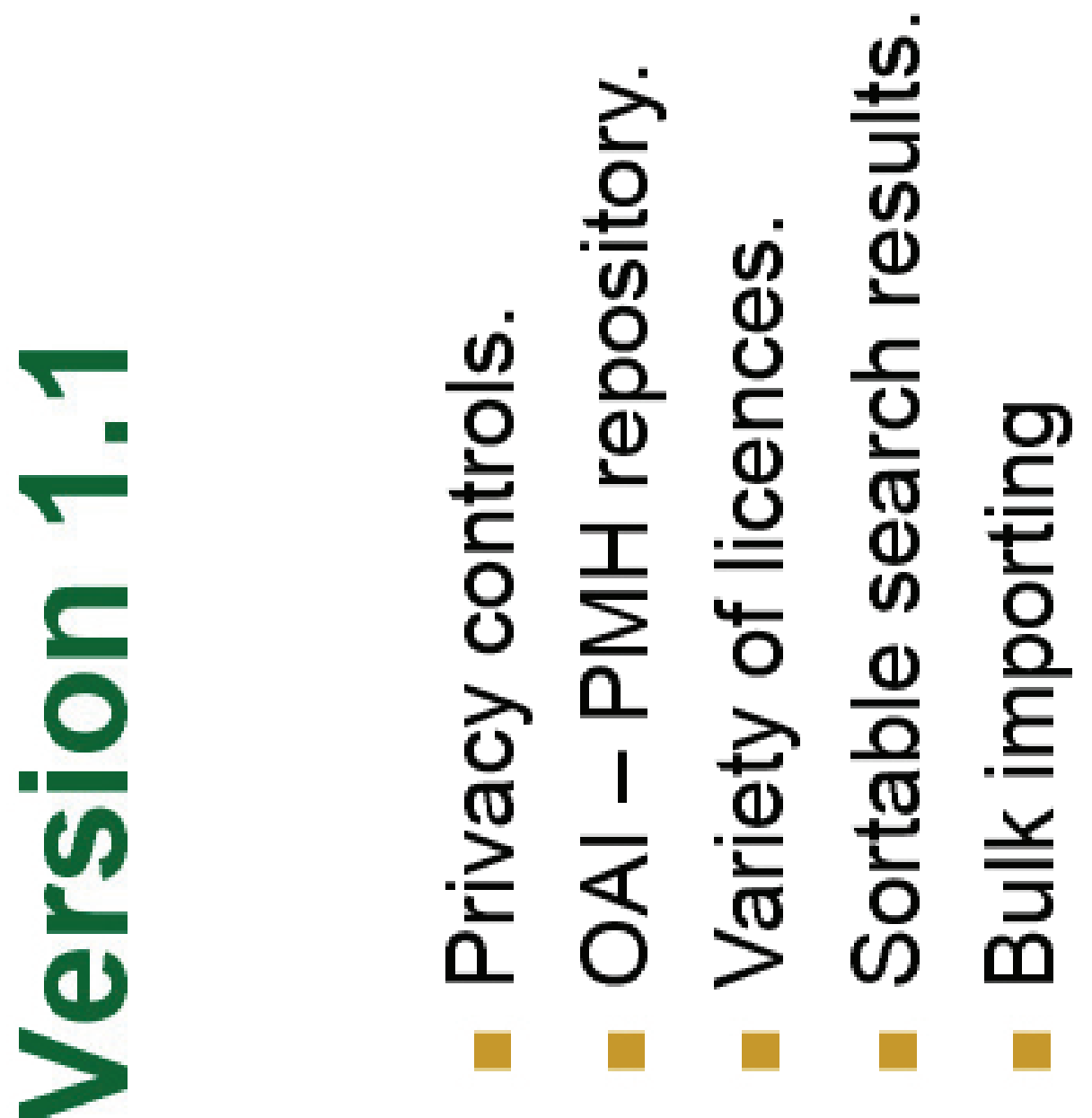




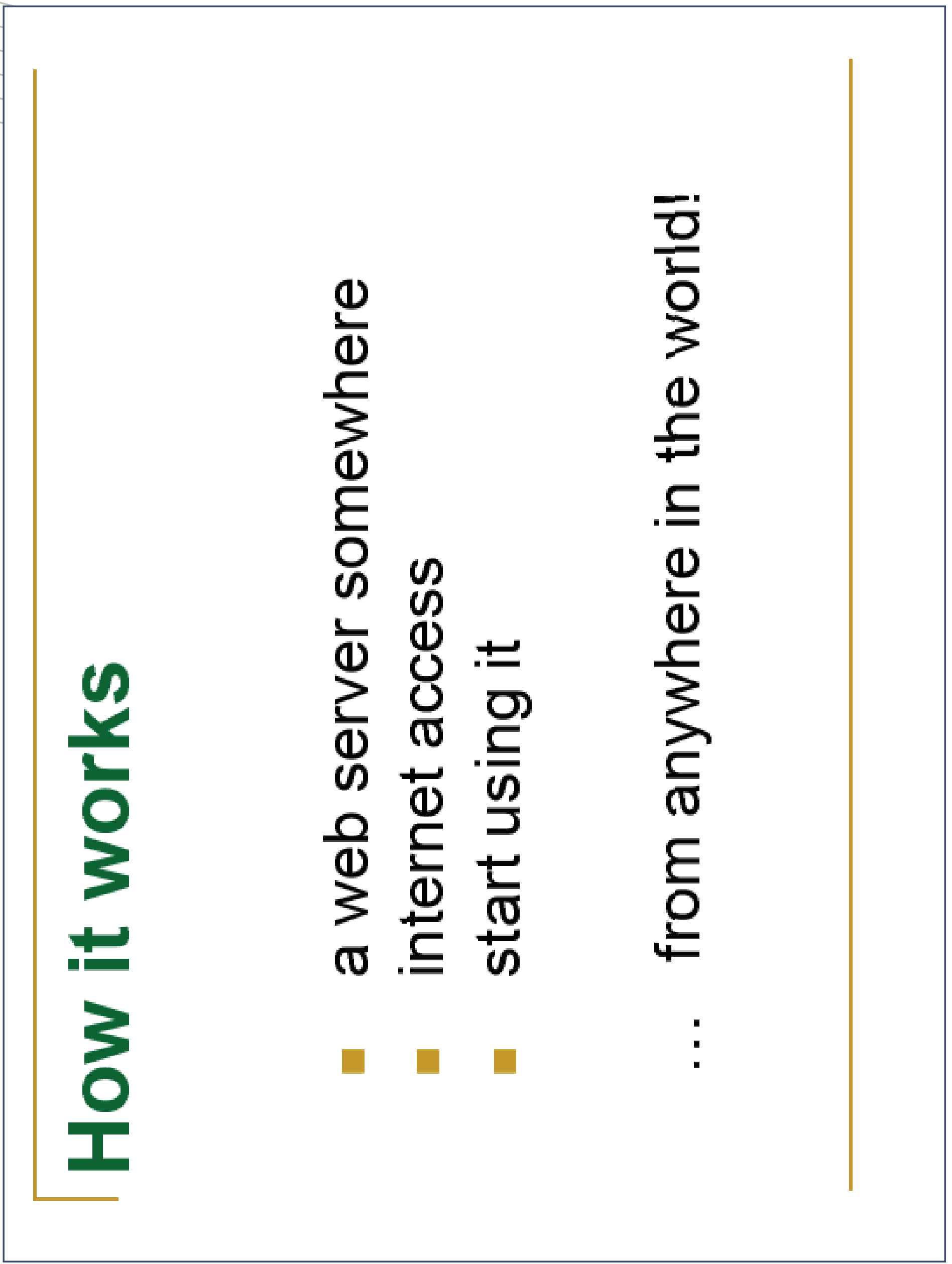


.

(4)

ت

(1)

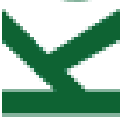

(10

v

(1)

อ)

음

.

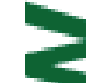

s

年

도

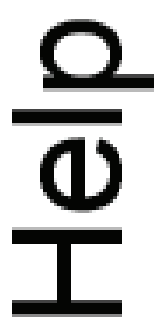

$\frac{c}{i}$

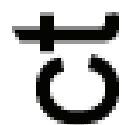

(T)
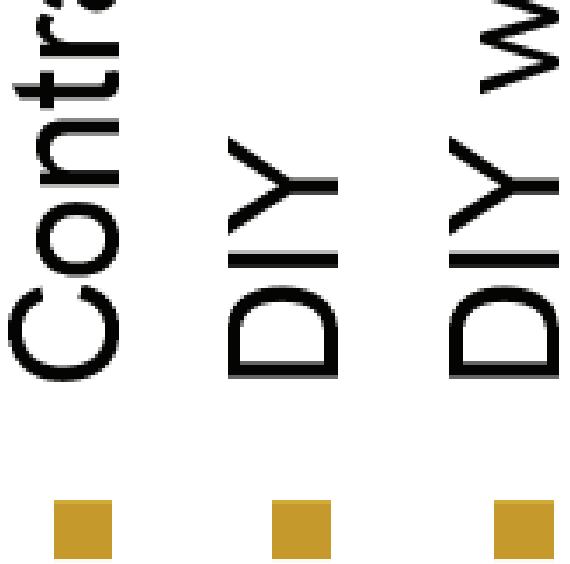


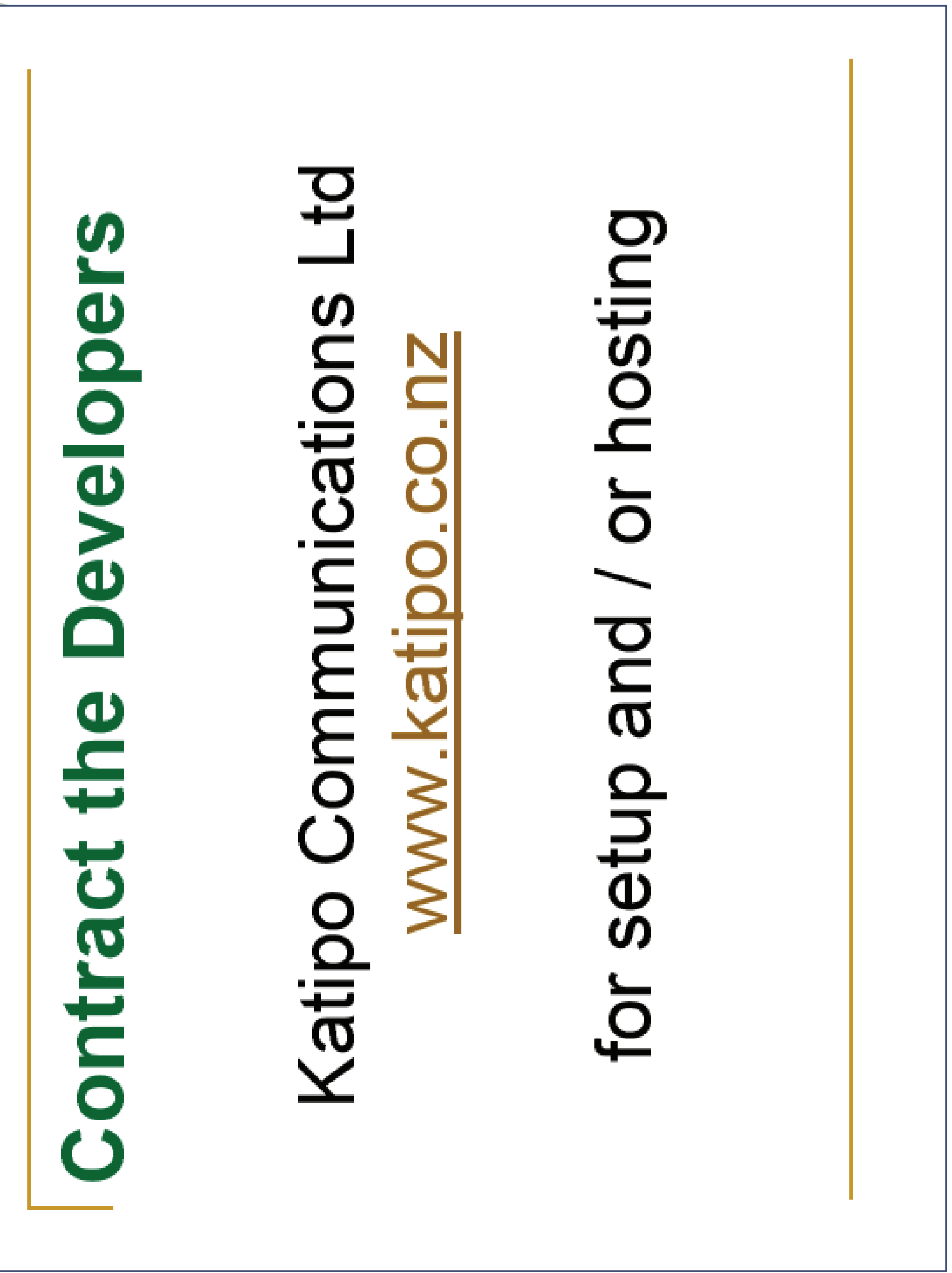




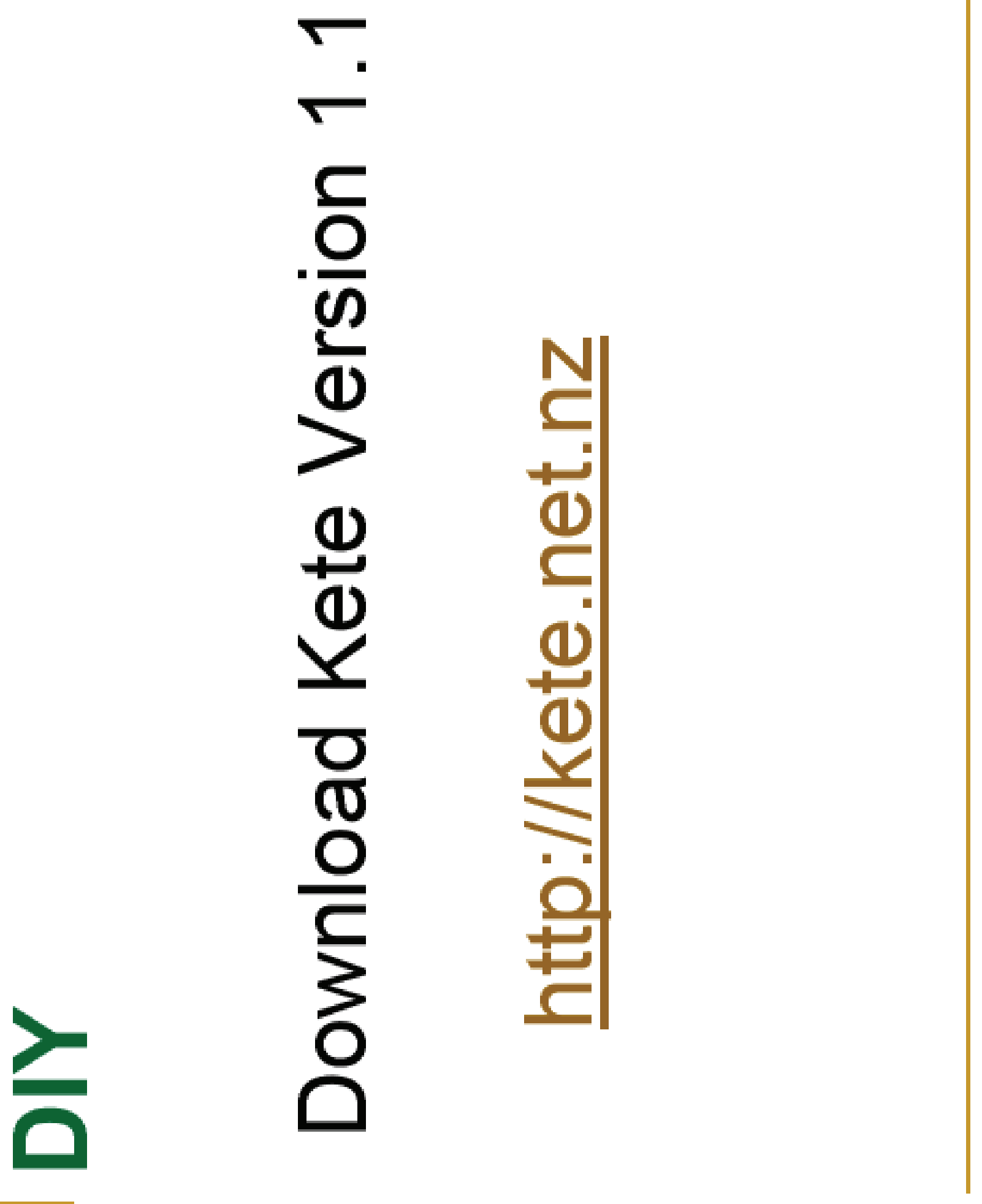




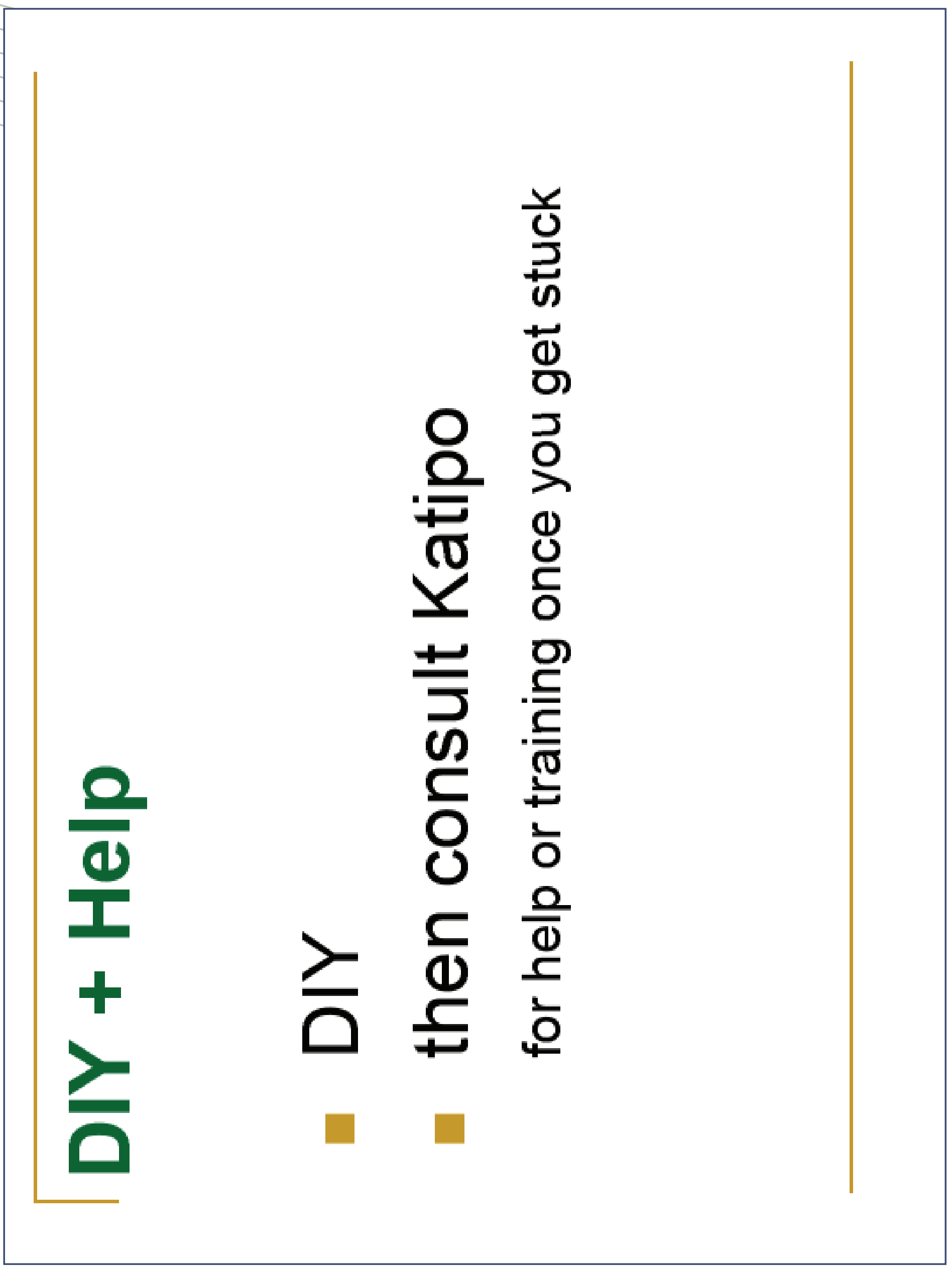




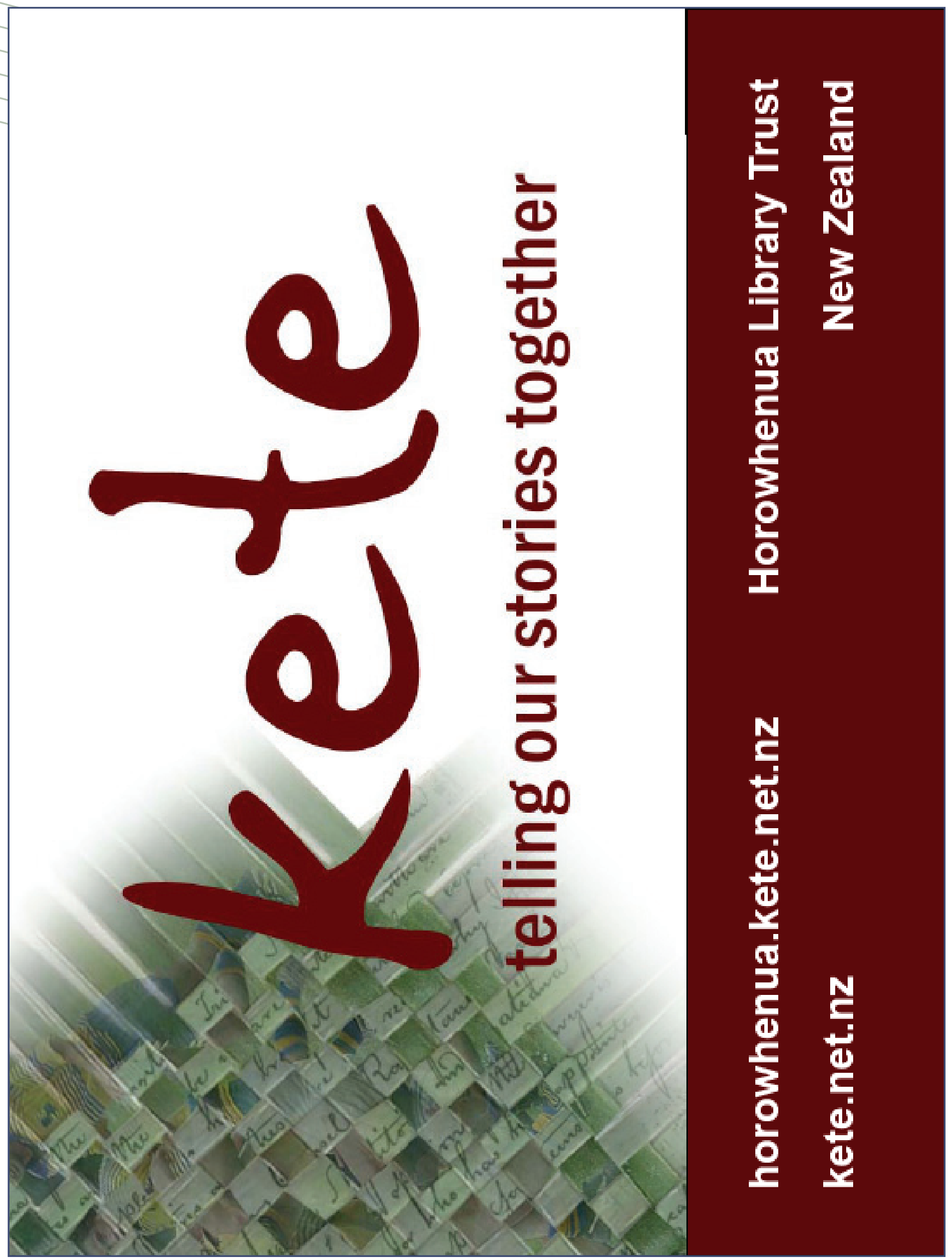

